\title{
The Relationship Between Insurance Coverage and Cancer Care: A Literature Synthesis
}

Nicole M. Marlow, Alexandre L. Pavluck, John Bian, Elizabeth M. Ward, and Michael T. Halpern

May 2009 


\section{About the Authors}

Nicole Marlow, MSPH, is a research associate in the Department of Biostatistics, Bioinformatics and Epidemiology at the Medical University of South Carolina, in Charleston, South Carolina.

Alex Pavluck, MPH, is an epidemiologist and Elizabeth Ward $\mathrm{PhD}$, is managing director in the American Cancer Society's Division of Surveillance and Health Policy Research in Atlanta, Georgia.

John Bian, PhD, is a health scientist in the Health Services Research and Development Service at the Atlanta VA Medical Center in Decatur, Georgia.

Michael Halpern, MD, PhD, is a senior health scientist in RTI International's Division of Health Services and Social Policy Research. He is based in RTI's Washington, DC, office.
RTI Press publication RR-0005-0905

This PDF document was made available from www.rti.org as a public service of RTI International. More information about RTI Press can be found at http://www.rti.org/rtipress.

RTI International is an independent, nonprofit research organization dedicated to improving the human condition by turning knowledge into practice. The RTI Press mission is to disseminate information about RTI research, analytic tools, and technical expertise to a national and international audience. RTI Press publications are peer-reviewed by at least two independent substantive experts and one or more Press editor.

\section{Suggested Citation}

Marlow, N.M., Pavluck, A.L., Bian, J., Ward, E.M., and Halpern, M.T. (2009). The Relationship Between Insurance Coverage and Cancer Care: A Literature Synthesis. RTI Press publication No. RR-0005-0905. Research Triangle Park, NC: RTI International. Retrieved [date] from http://www.rti.org/rtipress.
This publication is part of the RTI Press Research Report series.

RTI International

3040 Cornwallis Road

PO Box 12194

Research Triangle Park, NC

27709-2194 USA

Tel: $\quad+1.919 .541 .6000$

Fax: $\quad+1.919 .541 .5985$

E-mail: rtipress@rti.org

Web site: www.rti.org
(C)2009 Research Triangle Institute. RTI International is a trade name of Research Triangle Institute.

All rights reserved. Please note that this document is copyrighted and credit must be provided to the authors and source of the document when you quote from it. You must not sell the document or make a profit from reproducing it.

doi:10.3768/rtipress.2009.rr.0005.0905

www.rti.org/rtipress 


\section{The Relationship Between Insurance Coverage and Cancer Care: A Literature Synthesis}

\author{
Nicole M. Marlow, Alexandre L. Pavluck, John Bian, \\ Elizabeth M. Ward, and Michael T. Halpern
}

\section{Abstract}

This paper summarizes key literature on the relationship between health care insurance status and screening, diagnosis, and medical care patterns and outcomes for individuals with cancer. All studies included for this literature synthesis were identified using the National Library of Medicine's Medline database; only English language articles published in the past 10 years were considered. Based on article titles and abstracts, we selected the most relevant studies for full review and inclusion in this manuscript. Although the summarized literature is mixed, individuals who are uninsured or have insurance coverage through programs for low-income persons (e.g., Medicaid coverage) are significantly less likely to use cancer screening services and significantly more likely to present with advanced stage cancer at diagnosis and to have significantly worse survival. The relationship between insurance status and cancer treatment patterns is less clear, as fewer studies have examined this relationship, but the available evidence suggests that uninsured patients are less likely to receive optimal cancer care. The research reviewed here suggests that the benefits of extending appropriate insurance coverage to uninsured and underinsured individuals could be substantial. These benefits are likely to include reduced morbidity, improved quality of life, and increased survival for cancer patients as well as a positive impact on overall health care and societal costs.

\section{Contents \\ Introduction \\ Methods \\ Results \\ Identified Articles \\ Association Between Health Insurance and Cancer Screening Services \\ Association Between Health Insurance and Cancer Stage at Diagnosis \\ Association Between Health Insurance and Cancer Treatment Patterns or Outcomes \\ Discussion \\ Conclusions

23 \\ References \\ 23}

Acknowledgments Inside back cover 


\section{Introduction}

Many studies have indicated that lack of health insurance is associated with adverse patient outcomes. ${ }^{1-3}$ Although lack of insurance is a barrier for medical care access overall, uninsured adults face even greater barriers for preventive services and treatment for chronic illnesses, such as cancer, than for acute care. ${ }^{4}$ Thorpe and Howard reported that approximately 11 percent of cancer patients were uninsured. ${ }^{5}$ An additional 15 percent had coverage through Medicaid or other public programs (not including Medicare). Rates of being uninsured or insured through public programs are greater among racial/ethnic minority populations: 14 percent of black cancer patients were uninsured and 33 percent received insurance through public programs, while the rates for Hispanic cancer patients were 20 percent uninsured and 24 percent receiving public program insurance.

Not surprisingly, individuals who are either uninsured or enrolled in Medicaid have decreased rates of cancer screening, less optimal cancer treatment patterns, and worse cancer-related outcomes compared with those with Medicare coverage or private insurance. These differences are likely attributable to multiple factors, including the following:

- out-of-pocket expenditures for uninsured patients that deter use of preventive care services and physician encounters for suspicious symptoms

- decreased appreciation of the importance of appropriate and timely followup after abnormal screening results

- difficulty in identifying both primary care and specialist physicians willing to see uninsured and Medicaid patients, and greater delays for appointments among physicians willing to see these patient groups

- greater likelihood of receiving care at safety-net hospitals, which may be less likely to have the most recent medical care technology or physicians informed about current practices and guidelines

- decreased access to newer, more expensive therapies, which are generally more effective and/or have fewer side effects
- greater difficulties in navigating health care systems, including the complex set of health care providers involved in cancer care.

Beyond the potential impacts of being uninsured or having Medicaid coverage, other forms of insurance may also be associated with decreased access to care for individuals with cancer. Private health insurance includes a tremendous range of products, some of which have substantial out-of-pocket expenses (deductibles, co-payments, and co-insurance). These costs may deter the use of preventive care services (e.g., cancer screenings) and visits with physicians to evaluate suspicious symptoms that may represent early-stage cancers. Privately insured patients with more limited benefits may also be less likely to purchase expensive new medications because of substantial patient-borne costs.

In addition, patients in traditional fee-for-service plans may differ from those in managed care plans. Managed care plans (for privately insured or Medicare- or Medicaid-covered individuals), owing to their capitated payment structures, have increased financial incentives to keep enrollees healthy and diagnose diseases early. Thus, individuals in these plans may have more incentives or support for participating in screening programs and other preventive care activities.

A substantial body of literature has investigated the relationship between health care insurance status and medical care patterns and outcomes for individuals with cancer. This research report summarizes key literature regarding the relationship between health insurance coverage and cancer care. Our main objective is to provide a summary of published results to evaluate whether providing adequate insurance coverage for uninsured and underinsured individuals (i.e., those experiencing problems in accessing care despite having health insurance) could improve outcomes for cancer patients (e.g., earlier stage at diagnosis, increased access to treatments, improved quality of life outcomes during and after treatments, increased survival). Our synthesis is not a comprehensive review of all literature on this topic; our focus is on providing an overview and highlighting the main findings in this area. The summary (presented in the Results section) 
is divided into three sections: the association of insurance status with cancer screening services, with cancer stage at diagnosis, and with cancer treatment patterns and outcomes.

\section{Methods}

We identified all studies included for this literature synthesis using the National Library of Medicine's MEDLINE database. We used the Medical Subject Heading (MeSH) term Neoplasms in conjunction with the MeSH terms Insurance, Health, Medically Uninsured, or Health Services Accessibility. We included only English language articles, studies based on US populations, and studies published in the past 10 years. In addition, we also evaluated reference sections of reviewed articles to identify other studies for inclusion in this report. Study selection for inclusion in this literature synthesis was based on a comprehensive review of article titles and abstracts.

To provide an overview and highlight findings in this area, we selected only articles that clearly presented information on both patient insurance status and the specific type of cancer screening, diagnosis, treatment, or outcomes being assessed. Papers that did not clearly define different insurance status groups or did not provide information on cancer treatment patterns or outcomes separately for each insurance status group were excluded. Further, when multiple papers examined the link between insurance status and cancer treatment patterns or outcomes in the same (or very similar) populations, we included only the most recent studies. We selected the most relevant studies for full review and inclusion in this manuscript. Additionally, all articles selected for review for this report had to include multivariate statistical analyses as part of their study methodology, to control for other relevant factors while examining the potential impact of insurance status.

\section{Results}

\section{Identified Articles}

Based on the MEDLINE search parameters and review process described previously in the Methods section, we identified 25 publications providing information on the association between health insurance and cancer screening; 17 publications on insurance and cancer diagnosis; and 26 publications on insurance and cancer treatment and outcome. The literature summary presented in this section includes 15 of the articles on insurance and screening, 11 on insurance and diagnosis, and 18 on insurance and cancer treatment and outcome.

\section{Association Between Health Insurance and Cancer Screening Services}

A variety of studies have explored the relationship between insurance status and use of cancer screening services, mainly mammography, colon cancer screening, and cervical cancer screening. Studies included in this literature synthesis are summarized in Table 1 (following page). Most published studies have used data from national surveys, either the Behavioral Risk Factor Surveillance System (BRFSS) or the National Health Information Survey (NHIS). Studies in this literature synthesis are grouped below based on their source of data.

\section{Studies Using Data from the Behavioral Risk Factor} Surveillance System

The BRFSS, an annual health survey developed by the Centers for Disease Control and Prevention (CDC), is the world's largest ongoing telephonebased health survey system (http://www.cdc.gov/ brfss). Analyses of the BRFSS have consistently shown that lack of health insurance is associated with decreased rates of cancer screening. Qureshi et al. ${ }^{6}$ assessed the effects of insurance status on the likelihood of screening mammography utilization within the preceding 2 years among women ages 40 to 49 using data from the 1992-1993 BRFSS. Separate evaluations of the impact of health insurance on screening mammography utilization were performed for four racial/ethnic groups: non-Hispanic white, non-Hispanic black, Hispanic, and other. Adjusting for potential confounders (including other accessto-care variables, demographics, and behavioral characteristics), having health insurance significantly increased the likelihood of using screening mammography among all ethnic groups except the "other" group. 


\section{Table 1. Summary of literature relating to associations of insurance coverage with cancer prevention and screening}

Author and

Citation

Number

Data
Insurance Dependent

Category
Variable
Statistical

Analysis
Results

\section{A. Studies Using the BRFSS}

\section{Ayanian} et al. ${ }^{7}$

1997-1998

national

Adults

ages $18-64$

Long-term

$\mathrm{SM} \& \mathrm{CBE}$

Behavioral

$(\mathrm{N}=163,538)$

uninsured

w/in 2 yrs,

Risk Factor

Surveillance

System

(BRFSS) data

\begin{tabular}{|c|c|c|c|c|}
\hline $\begin{array}{l}\text { loannou } \\
\text { et al. }{ }^{8}\end{array}$ & 1999 BRFSS & $\begin{array}{l}\text { Adults } \\
\text { ages } 50+ \\
(\mathrm{N}=61,068)\end{array}$ & $\begin{array}{l}\text { Uninsured, } \\
\text { private, } \\
\text { Medicaid, } \\
\text { Medicare, } \\
\text { Military/ } \\
\text { CHAMPUS/ } \\
\text { VA, or other }\end{array}$ & $\begin{array}{l}\text { CRC screening: } \\
\text { FOBT w/in } 1 \text { yr } \\
\text { and/or S/C } \\
\text { w/in } 5 \text { yrs }\end{array}$ \\
\hline $\begin{array}{l}\text { Pollack } \\
\text { et al. }{ }^{9}\end{array}$ & $\begin{array}{l}2002 \text { BRFSS } \\
\text { data }\end{array}$ & $\begin{array}{l}\text { Adults } \\
\text { ages } 50+ \\
(\mathrm{N}=110,413)\end{array}$ & $\begin{array}{l}\text { Insured and } \\
\text { uninsured }\end{array}$ & $\begin{array}{l}\text { CRC screening: } \\
\text { FOBT w/in } 1 \text { yr } \\
\text { and/or S/C } \\
\text { w/in } 10 \text { yrs }\end{array}$ \\
\hline
\end{tabular}

short-term

uninsured

(<1 yr),

insured

Pap smear

w/in 3 yrs, FOBT

w/in 2 yrs, \&

sigmoidoscopy

w/in 5 yrs

(any public

or private

source)

\begin{tabular}{llllll}
\hline $\begin{array}{l}\text { Qureshi } \\
\text { et al. }{ }^{6}\end{array}$ & 1992-1993 & Women & Reported & Use of SM w/in & Multivariate \\
& BRFSS & $\begin{array}{l}\text { ages 40-49 } \\
\text { availability }\end{array}$ & $\begin{array}{l}\text { 2 yrs (excluded } \\
\text { of any form } \\
\text { of healthcare }\end{array}$ & $\begin{array}{l}\text { women } \\
\text { w/ diagnostic }\end{array}$ & \\
& & & & & \\
& & & & & \\
& & & &
\end{tabular}

Multivariate

logistic regression

to compute and

report adjusted

proportions of

each insurance

group that had

not received

screening

Multivariate

logistic regression

analysis of

predictors of

screening using

STATA to account

for the sampling

and weighting

processes

Multivariate

logistic regression

The adjusted odds of receiving CRC

screening were significantly lower for respondents who reported having no health insurance (FOBT: OR=0.63 [95\% $\mathrm{Cl}=0.56-0.72], \mathrm{S} / \mathrm{C}: \mathrm{OR}=0.63[95 \% \mathrm{Cl}=0.56-$ $0.70])$.

Having health insurance coverage significantly increased the likelihood of $\mathrm{SM}$ among all ethnic groups (All: $\mathrm{OR}=2.16$ [95\% $\mathrm{Cl}=1.8-2.6]$, non-Hispanic whites: $\mathrm{OR}=2.4[95 \% \mathrm{Cl}=2.0-3.0]$, non-Hispanic blacks: $\mathrm{OR}=1.5[95 \% \mathrm{Cl}=1.0-2.3]$, Hispanics: $\mathrm{OR}=2.5[95 \% \mathrm{Cl}=1.5-4.2]$ ) excluding the "other" ethnic group $(\mathrm{OR}=1.1,95 \% \mathrm{Cl}=0.5$ 2.3).

\begin{tabular}{|c|c|c|c|c|}
\hline $\begin{array}{l}\text { Ross } \\
\text { et al. }{ }^{10}\end{array}$ & 2002 BRFSS & $\begin{array}{l}\text { Adults } \\
\text { ages 18-64 } \\
(\mathrm{N}=194,943)\end{array}$ & $\begin{array}{l}\text { Insured and } \\
\text { uninsured }\end{array}$ & $\begin{array}{l}\text { Pap smears } \\
\text { w/in } 3 \text { yrs, SM } \\
\text { w/in } 2 \text { yrs, and } \\
\text { CRC screening } \\
\text { (FOBT w/in } 2 \\
\text { yrs or S/C w/in } \\
5 \text { yrs) }\end{array}$ \\
\hline
\end{tabular}
$\begin{array}{ll}x^{2} \text { tests and } & \text { Unadjusted analyses showed that those } \\ \text { multivariate } & \text { with health insurance had proportionately }\end{array}$ logistic regression greater use of all cancer prevention services $(p<.01)$. Multivariate analyses further showed that increased income did not attenuate the significant associations between being uninsured and using fewer services.

\section{B. Studies Using the NHIS}

\begin{tabular}{|c|c|c|c|c|c|c|}
\hline $\begin{array}{l}\text { Coughlin } \\
\text { et al. }{ }^{11}\end{array}$ & $\begin{array}{l}2000 \text { NHIS } \\
\text { cancer } \\
\text { control } \\
\text { topical } \\
\text { module }\end{array}$ & $\begin{array}{l}\text { Women } \\
\text { ages } 40+ \\
(\mathrm{N}=10,403)\end{array}$ & $\begin{array}{l}\text { Insured and } \\
\text { uninsured }\end{array}$ & $\begin{array}{l}\text { Mammography } \\
\text { use \& CBE w/in } \\
2 \text { yrs }\end{array}$ & $\begin{array}{l}\text { Multivariate } \\
\text { logistic regression }\end{array}$ & $\begin{array}{l}\text { Adjusted analyses showed a significant } \\
\text { and positive association for health } \\
\text { insurance coverage with mammography } \\
(\mathrm{OR}=2.31,95 \% \mathrm{Cl} 1.88-2.84) \text { and } \mathrm{CBE} \\
(\mathrm{OR}=1.99,95 \% \mathrm{Cl} 1.59-2.49) \text {. }\end{array}$ \\
\hline $\begin{array}{l}\text { Echeverria \& } \\
\text { Carrasquillo } \\
\end{array}$ & $\begin{array}{l}2000 \text { NHIS } \\
\text { data }\end{array}$ & $\begin{array}{l}\text { Women ages } \\
18-70 \\
(\mathrm{~N}=18,342)\end{array}$ & $\begin{array}{l}\text { Insured and } \\
\text { uninsured }\end{array}$ & $\begin{array}{l}\text { Pap smears w/in } \\
3 \text { yrs for women } \\
18-65 ; \text { SM w/in } \\
2 \text { yrs for women } \\
50-70\end{array}$ & $\begin{array}{l}\text { Multivariate } \\
\text { logistic regression } \\
\text { to report adjusted } \\
\text { and unadjusted } \\
\text { screening } \\
\text { proportions }\end{array}$ & $\begin{array}{l}\text { Adjusting for covariates, including health } \\
\text { insurance and usual source of care, Pap } \\
\text { smears remained significantly less likely } \\
\text { ( } p<0.01) \text { among noncitizens than among } \\
\text { US-born women }(<0.01) \text {, yet there were no } \\
\text { significant disparities in SM between these } \\
\text { groups. }\end{array}$ \\
\hline
\end{tabular}




\section{Table 1. Summary of literature relating to associations of insurance coverage with cancer prevention and screening (continued)}

\begin{tabular}{|c|c|c|c|c|}
\hline $\begin{array}{l}\text { Author and } \\
\text { Citation } \\
\text { Number }\end{array}$ & Data & Sample & $\begin{array}{l}\text { Insurance } \\
\text { Category }\end{array}$ & $\begin{array}{l}\text { Dependent } \\
\text { Variable }\end{array}$ \\
\hline \multicolumn{5}{|c|}{ B. Studies Using the NHIS (continued) } \\
\hline Potosky et al. ${ }^{14}$ & 1992 NHIS & $\begin{array}{l}\text { Women } \\
\text { ages } 18+\text { for } \\
\text { Pap smear } \\
(\mathrm{N}=6,841) ; \\
\text { men and } \\
\text { women ages } \\
40+\text { for all } \\
\text { other tests } \\
(\mathrm{N}=2,614 \\
\& 3,803 \text {, } \\
\text { respectively) }\end{array}$ & $\begin{array}{l}\leq \text { Age } 64 \text { : HMO/ } \\
\text { PPO, private } \\
\text { fee-for-service } \\
\text { (FFS), Medicaid } \\
\text { not managed } \\
\text { care, \& } \\
\text { uninsured; ages } \\
65+\text { : Medicare } \\
\text { W/ private FFS, } \\
\text { Medicare w/ } \\
\text { Medicaid, HMO/ } \\
\text { PPO Medicare, } \\
\text { Medicare only }\end{array}$ & $\begin{array}{l}\text { PRSIG w/in } 3 \text { yrs, } \\
\text { Pap smear } \\
\text { w/in } 3 \text { yrs, SM } \\
\text { w/in } 2 \text { yrs, CBE } \\
\text { w/in } 2 \text { yrs, DRE } \\
\text { w/in } 2 \text { yrs, and } \\
\text { FOBT w/in } 2 \\
\text { yrs (excluded } \\
\text { respondents } \\
\text { with receipt of } \\
\text { testing for a healt } \\
\text { problem) }\end{array}$ \\
\hline
\end{tabular}

Statistical Analysis Results

\begin{tabular}{|c|c|c|c|c|c|c|}
\hline $\begin{array}{l}\text { Sambamoorthi } \\
\& \text { McAlpine }^{12}\end{array}$ & $\begin{array}{l}1996 \text { Medical } \\
\text { Expenditure } \\
\text { Panel Survey } \\
\text { (MEPS), which } \\
\text { collected } \\
\text { more detailed } \\
\text { information } \\
\text { form a subset } \\
\text { of NHIS } \\
\text { respondents }\end{array}$ & $\begin{array}{l}\text { Women } \\
\text { ages 21-64 } \\
(\mathrm{N}=6,218)\end{array}$ & $\begin{array}{l}\text { Private, public, } \\
\text { and uninsured }\end{array}$ & $\begin{array}{l}\text { Pap smear w/in } 3 \\
\text { yrs and SM w/in } \\
2 \text { yrs }\end{array}$ & $\begin{array}{l}\text { Multivariate logistic } \\
\text { regression }\end{array}$ & $\begin{array}{l}\text { Health insurance was } \\
\text { associated with a } \\
\text { significantly increased use } \\
\text { of services for all groups } \\
\text { except public FFS compared } \\
\text { with uninsured. }\end{array}$ \\
\hline Ward et al. ${ }^{15}$ & 2005-2006 NHIS & $\begin{array}{l}\text { Women ages } \\
40-64 \text { for SM, } \\
\& 18+\text { for Pap } \\
\text { smear; men \& } \\
\text { women ages } \\
50+\text { for CRC } \\
\text { screening; } \\
\text { men ages } \\
\text { 50+ for PSA }\end{array}$ & $\begin{array}{l}\text { All, private, } \\
\text { Medicaid, } \\
\text { uninsured } \\
\text { (at time of } \\
\text { interview), } \\
\text { uninsured for } \\
>12 \text { months }\end{array}$ & $\begin{array}{l}\text { Proportion of } \\
\text { the population } \\
\text { sub-group } \\
\text { that received } \\
\text { appropriate } \\
\text { screening (SM } \\
\text { w/in } 2 \text { yrs, Pap } \\
\text { smear w/in } 3 \mathrm{yrs,} \\
\text { FOBT w/in past yr } \\
\text { or endoscopy } \\
\text { w/in } 10 \text { yrs, PSA } \\
\text { w/in past yr) }\end{array}$ & $\begin{array}{l}\text { Stratified } \\
\text { descriptive analyses }\end{array}$ & $\begin{array}{l}\text { The likelihood of receiving } \\
\text { recommended screening } \\
\text { varies markedly by } \\
\text { insurance status. }\end{array}$ \\
\hline \multicolumn{7}{|c|}{ C. Studies Using Other Data Sources } \\
\hline Almeida et al. ${ }^{17}$ & $\begin{array}{l}1997 \text { National } \\
\text { Survey of } \\
\text { America's } \\
\text { Families (NSAF) }\end{array}$ & $\begin{array}{l}\text { Low-income } \\
\text { women } \\
\text { ages }<65 \\
(\mathrm{~N}=11,172)\end{array}$ & $\begin{array}{l}\text { Medicaid or } \\
\text { other public } \\
\text { plan, private, or } \\
\text { uninsured }\end{array}$ & $\begin{array}{l}\text { Pap smear w/in the } \\
\text { past } y r, C B E \text { w/in } \\
\text { the past } y r\end{array}$ & $\begin{array}{l}\text { Multivariate } \\
\text { ordinary least } \\
\text { squares regression } \\
\text { analyses }\end{array}$ & $\begin{array}{l}\text { Adjusting for other } \\
\text { predictors, those uninsured } \\
\text { were significantly less likely } \\
\text { ( } p<0.05) \text { than those with } \\
\text { Medicaid and other public } \\
\text { insurance to receive Pap } \\
\text { smears }(\beta=-0.13) \text { and CBE } \\
(\beta=-0.11) .\end{array}$ \\
\hline $\begin{array}{l}\text { Carrasquillo \& } \\
\text { Pati }^{16}\end{array}$ & $\begin{array}{l}\text { April-November } \\
2001 \\
\text { Commonwealth } \\
\text { Fund's (CMWF) } \\
\text { Health Care } \\
\text { Quality Survey } \\
\text { (HCQS) }\end{array}$ & $\begin{array}{l}\text { Women ages } \\
18-65 \text { for } \\
\text { Pap smear, } \\
\text { women } \\
40-70 \text { for } \\
\text { mammogram } \\
(\mathrm{N}=3,596)\end{array}$ & $\begin{array}{l}\text { Private, } \\
\text { government, or } \\
\text { uninsured }\end{array}$ & $\begin{array}{l}\text { Pap smear \& SM } \\
\text { w/in } 2 \text { yrs }\end{array}$ & $\begin{array}{l}\text { Multivariate } \\
\text { logistic regression } \\
\text { models to estimate } \\
\text { the adjusted } \\
\text { percentages of } \\
\text { women in each } \\
\text { group who received } \\
\text { a Pap-smear and SM }\end{array}$ & $\begin{array}{l}\text { In the final models, health } \\
\text { insurance remained the } \\
\text { strongest independent } \\
\text { predictor of screening } \\
\text { (Pap smear: } \mathrm{OR}=0.49 \text {, } \\
95 \% \mathrm{Cl}=0.32-0.75 ; \mathrm{SM} \text { : } \\
\mathrm{OR}=0.23,95 \% \mathrm{Cl}=0.12-0.43 \text {; } \\
\text { uninsured vs. privately } \\
\text { insured). }\end{array}$ \\
\hline
\end{tabular}




\section{Table 1. Summary of literature relating to associations of insurance coverage with cancer prevention and screening (continued)}

\begin{tabular}{|c|c|c|c|c|c|}
\hline $\begin{array}{l}\text { Author and } \\
\text { Citation } \\
\text { Number }\end{array}$ & Data & Sample & $\begin{array}{l}\text { Insurance } \\
\text { Category }\end{array}$ & $\begin{array}{l}\text { Dependent } \\
\text { Variable }\end{array}$ & $\begin{array}{l}\text { Statistical } \\
\text { Analysis }\end{array}$ \\
\hline \multicolumn{6}{|c|}{ C. Studies Using Other Data Sources (continued) } \\
\hline Chen et al. ${ }^{18}$ & $\begin{array}{l}2001 \text { California } \\
\text { Health Interview } \\
\text { Survey }\end{array}$ & $\begin{array}{l}\text { Adults } \\
\text { ages } 65+ \\
(\mathrm{N}=11,161)\end{array}$ & $\begin{array}{l}\text { Medicare w/ } \\
\text { Medicaid, } \\
\text { Medicare } \\
\text { w/ private- } \\
\text { insurance, } \\
\text { Medicare only, } \\
\text { other insurance, } \\
\text { uninsured }\end{array}$ & $\begin{array}{l}\text { SM w/in } 2 \text { yrs for } \\
\text { women and CRC } \\
\text { screening (FOBT } \\
\text { w/in the } 2 \text { yrs } \\
\text { and/or receipt } \\
\text { of lower GI } \\
\text { endoscopy } \\
\text { w/in } 5 \text { yrs) }\end{array}$ & $\begin{array}{l}\text { Multivariate } \\
\text { logistic regression } \\
\text { was used to test } \\
\text { the effect of } \\
\text { type of health } \\
\text { insurance receipt } \\
\text { of screening } \\
\text { services }\end{array}$ \\
\hline
\end{tabular}

Results

\section{Patients in each insurance} category, with the exception of the "other insurance" group, were significantly less likely $(p<0.01)$ than patients with Medicare plus private insurance to receive screening services (OR [95\% $\mathrm{Cl}$ ] for CRC screening: 0.7 [0.7-0.9] for duals, 0.7 [0.50.9 ] for Medicare only, and 0.3 [0.1-0.6] for uninsured; $O R$ [95\% CI] for SM: 0.7 [0.6-0.9]) for Medicare w/Medicaid, 0.5 [0.4-0.6] for Medicare only, and 0.2 [0.1-0.5] for uninsured).

\begin{tabular}{|c|c|c|c|c|c|c|}
\hline $\begin{array}{l}\text { Koroukian et } \\
\text { al. }{ }^{19}\end{array}$ & $\begin{array}{l}1999 \text { Medicare } \\
\text { Denominator } \\
\text { File, the } \\
\text { Medicare } \\
\text { Outpatient } \\
\text { Standard } \\
\text { Analytic Files, } \\
\text { and Physician } \\
\text { Supplier Part B } \\
\text { files; } 1998 \text { Area } \\
\text { Resource File }\end{array}$ & $\begin{array}{l}\text { Adults ages } \\
65+(\mathrm{N}=22.7 \\
\text { million })\end{array}$ & $\begin{array}{l}\text { Dual enrollees } \\
\text { and non-duals } \\
\text { (Medicare } \\
\text { enrollees not } \\
\text { also enrolled in } \\
\text { Medicaid) }\end{array}$ & $\begin{array}{l}\text { CRC screening } \\
\text { (FOBT, FLEX, and } \\
\text { COL) at least once } \\
\text { during the study } \\
\text { period }\end{array}$ & $\begin{array}{l}\text { Hierarchical } \\
\text { logistic regression } \\
\text { analysis }\end{array}$ & $\begin{array}{l}\text { Adjusted results showed a } \\
\text { significant }(p<0.001) \text { decrease } \\
\text { in CRC screening (FOBT: } \\
\text { OR }=0.48 \text {, FLEX: OR }=0.55 \text {. } \\
\text { FLEX and COL: } 0.60, C O L \text { only: } \\
0.85 \text { ) among duals compared } \\
\text { with non-duals. }\end{array}$ \\
\hline Parker et al. ${ }^{20}$ & $\begin{array}{l}\text { 1993-1994 } \\
\text { Health Care } \\
\text { Financing } \\
\text { Administration } \\
\text { data and } 1990 \\
\text { US Census data }\end{array}$ & $\begin{array}{l}\text { Female } \\
\text { California } \\
\text { residents } \\
\text { ages } 65+\text { with } \\
\text { Medicare } \\
\text { coverage } \\
(\mathrm{N}=837,413)\end{array}$ & $\begin{array}{l}\text { Medicare } \\
\text { only and dual } \\
\text { enrollees }\end{array}$ & $\begin{array}{l}\text { Receipt of at least } \\
\text { one mammogram } \\
\text { during the study } \\
\text { period }\end{array}$ & $\begin{array}{l}\text { Bivariate } \\
\text { comparisons } \\
\text { and multivariate } \\
\text { logistic regression }\end{array}$ & $\begin{array}{l}\text { Women with dual coverage } \\
\text { were significantly less likely } \\
(\mathrm{OR}=0.59,95 \% \mathrm{Cl}=0.58- \\
0.60) \text { than women with } \\
\text { Medicare only to receive a } \\
\text { mammogram. }\end{array}$ \\
\hline
\end{tabular}

BRFSS = Behavioral Risk Factor Surveillance System, $\mathrm{CBE}=$ clinical breast exam, $\mathrm{Cl}=$ confidence interval, $\mathrm{COL}=\mathrm{colonoscopy}, \mathrm{CRC}=\mathrm{colorectal}$ cancer, $\mathrm{DRE}=\mathrm{digital}$ rectal exam, duals = dual Medicare-Medicaid enrollees, FFS = fee-for-service, FLEX = flexible sigmoidoscopy, FOBT = fecal occult blood test, GI = gastrointestinal, $\mathrm{HMO}$ = health maintenance organization, MEPS = Medical Expenditure Panel Survey, NHIS = National Health Interview Survey, PPO = preferred provider organization, PRSIG $=$ proctosigmoidoscopy, $\mathrm{PSA}=$ prostate-specific antigen, $\mathrm{S} / \mathrm{C}=$ sigmoidoscopy/colonoscopy, $\mathrm{SM}=$ screening mammography, $\mathrm{yr}=\mathrm{year}(\mathrm{s})$.

Ayanian et al. ${ }^{7}$ examined rates of clinical breast examination, screening mammography, Pap smear, fecal occult blood test (FOBT), and sigmoidoscopy rates using data from the 1997-1998 BRFSS. After adjusting for potential confounders, long-term uninsured individuals were significantly less likely to have each screening service $(p<0.001)$ and short-term uninsured individuals were significantly less likely to have screening mammography and Pap smears $(p<0.001)$. Ioannou et al. ${ }^{8}$ presented similar findings using data from the 1999 BRFSS.
These investigators reported that after adjusting for other predictors, the lowest calculated prevalence of cancer screening was found among the uninsured (20.4 percent) and those with Medicaid insurance (29.2 percent). Pollack et al. ${ }^{9}$ provided similar results from the 2002 BRFSS, reporting that rates of colorectal cancer screening (FOBT, sigmoidoscopy, colonoscopy) were lowest for respondents who reported having no health insurance (adjusted odds ratio $[\mathrm{OR}]=0.63,95 \% \mathrm{CI}=0.56-0.72)$. 
Ross et al. ${ }^{10}$ also examined the relationship between insurance status and utilization of Pap smears, screening mammography, and FOBT or sigmoidoscopy/colonoscopy, using data from the 2002 BRFSS. After adjusting for income and other potential confounders (including self-reported health status and sociodemographic variables), insurance coverage was significantly associated with increased use of all services. Even among the highest income group, lack of insurance was associated with decreased use of these preventive services. These results suggest that efforts to increase screening utilization should consider expanding insurance coverage/enrollment for both low- and high-income adults.

\section{Studies Using Data from the National Health Interview Survey (NHIS)}

The NHIS, administered by the US National Center for Health Statistics, is a major source of information on the health of the civilian noninstitutionalized population of the United States (http://www.cdc .gov/nchs/about/major/nhis/hisdesc.htm). Similar to analyses of the results from the BRFSS, analyses of the NHIS have consistently indicated that being uninsured is associated with decreased rates of participation in cancer screening. Coughlin et al., ${ }^{11}$ using data from the 2000 NHIS, found that having health insurance was one of the strongest predictors for women's having had a mammogram or clinical breast examination over a 2-year period, regardless of race or ethnicity. Sambamoorthi and McAlpine ${ }^{12}$ used data from the 1996 Medical Expenditure Panel Survey (MEPS), a more detailed medical care survey involving a subset of NHIS respondents. These investigators reported that compared with uninsured individuals, those with public or private insurance had significant increases in receipt of Pap smear or screening mammography (except for the public feefor-service group with respect to receipt of screening mammography).

Echeverria and Carrasquillo ${ }^{13}$ investigated the effect of citizenship status and health insurance on cancer screening rates, including Pap smear use among women ages 18-65 and mammograms among women ages 50-70, using 2000 NHIS data. They found that noncitizens and naturalized citizens were less likely to report mammography and Pap smears than were USborn women $(p<0.01)$. Yet, for mammography, the effect of citizenship status on health insurance became nonsignificant after controlling for health insurance coverage and usual source of care, suggesting that lack of health insurance coverage and a usual source of care explained the observed citizenship-based disparities.

Not only are insurance coverage and screening utilization associated, but significant differences also exist among specific insurance types regarding use of cancer screening services. Potosky et al. ${ }^{14}$ used 1992 NHIS data to estimate the proportions of individuals screened with Pap smears, proctosigmoidoscopy, clinical breast examination, screening mammography, digital rectal examination, and FOBT by insurance type, adjusting for potential confounders (including socioeconomic, demographic, and health status variables).

For those ages 64 and younger, all screenings except proctosigmoidoscopy were significantly more likely for those with Medicaid than for the uninsured; Pap smears were significantly more likely for those with private fee-for-service insurance (FFS) than for those with Medicaid; and FOBT and digital rectal examination were significantly more likely for those with health maintenance organization/preferred provider organization (HMO/PPO) coverage than for those with private FFS.

For those ages 65 and older, Medicare HMO/PPO enrollees were significantly more likely than Medicare enrollees with supplemental private FFS to have had screening mammography and FOBT. Further, individuals with Medicare and supplemental private FFS were more significantly more likely to have had all screening exams except proctosigmoidoscopy than were individuals with dual Medicare/Medicaid coverage. This comparatively lower rate of screening exams among dual enrollees may reflect lower socioeconomic status and associated decreased health literacy for these individuals and/or decreased physician and medical care facility payment for dual enrollees compared with non-dual enrollees in some instances. Those with Medicare only (i.e., without supplemental insurance) and those with dual Medicare/Medicaid coverage did not differ significantly regarding these variables. 
Ward et al. ${ }^{15}$ analyzed 2005-2006 NHIS data and found that the likelihood of receiving recommended cancer screening tests (mammography in the past 2 years among women ages 40 to 64, Pap test in the past 3 years among women ages 18 and older, colorectal cancer screening test according to recommended guidelines among men and women ages 50 and older, and prostate-specific antigen test among men ages 50 and older) varies markedly by insurance status, with privately insured patients showing greater screening rates than those with Medicaid or the uninsured. Additionally, in separate analyses of the likelihood of receiving mammography and colorectal cancer screening stratified by race and ethnicity (non-Hispanic white, non-Hispanic black, and Hispanic), level of education, and insurance status (insured versus uninsured), health insurance was an important predictor across all racial/ethnic and level of education groups. At all levels of education, individuals with health insurance are approximately twice as likely as those without health insurance to have had mammography or colorectal cancer screening.

\section{Studies Using Other Data Sources}

A variety of other survey and data sources have been used to assess the relationship between insurance status and participation in cancer screening. In general, results are similar to those from the BRFSS and NHIS: uninsured individuals are less likely to receive cancer screening.

Carrasquillo and Pati ${ }^{16}$ analyzed data from the April-November 2001 Commonwealth Fund's Health Care Quality Survey. These investigators reported that after adjusting for potential confounders (including usual source of care), lack of insurance coverage remained the strongest independent predictor for not receiving a Pap smear $(\mathrm{OR}=0.49,95 \% \mathrm{CI}=0.32$ $0.75)$ or screening mammography $(\mathrm{OR}=0.23,95 \%$ $\mathrm{CI}=0.12-0.43)$.

Almeida et al. ${ }^{17}$ used 1997 National Survey of America's Families data to compare use of health care services by low-income women with Medicaid or other public insurance coverage (including other state-sponsored insurance programs and CHAMPUS), private insurance, or no insurance. Adjusting for demographic, socioeconomic, geographic, and health-status indicators, the probability of obtaining a Pap smear or clinical breast examination did not differ significantly between women with public coverage and those with private insurance. However, women with public coverage were significantly more likely than uninsured women to obtain both a Pap smear and a clinical breast examination.

A small number of studies using other data sources have also explored associations between types of insurance coverage and receipt of cancer screening. Chen et al. ${ }^{18}$ conducted a state-level analysis of an elderly study population (99.6 percent of whom had Medicare coverage) using data from the 2001 California Health Interview Survey. These investigators found that respondents with Medicare and Medicaid, Medicare only, or no insurance were significantly less likely to receive colorectal cancer screening and mammograms than were those with Medicare plus supplemental private insurance. Although the number of individuals with no insurance (42 of 10,724 individuals, or approximately 0.4 percent of the study population) was small, it was sufficient to indicate a highly significant $(p<0.001)$ association with a person's likelihood of having cancer screening tests.

Koroukian et al. ${ }^{19}$ used 1999 Medicare data to assess disparities in colorectal cancer screening (FOBT, flexible sigmoidoscopy, and colonoscopy) among elderly dual Medicare-Medicaid enrollees (or duals) versus non-duals (i.e., individuals with Medicare but not Medicaid coverage). Results showed a significantly $(p<0.001)$ lower prevalence of colorectal cancer screening among duals than among non-duals after adjusting for individual-level and county-level factors.

Parker et al., ${ }^{20}$ using Medicare data from 1993 and 1994 for female California residents ages 65 or older, also found that those with dual Medicaid and Medicare were significantly less likely than those with Medicare only to receive mammography, after controlling for race and ethnicity, age, and certain community-level factors. As noted above, these results could reflect differences in factors related to socioeconomic status and/or reimbursements between the dual and non-dual populations. 
Overall, the results of these studies highlight the importance of insurance coverage as a predictor of cancer screening utilization and demonstrate that differences in utilization among uninsured compared with insured individuals persist across racial/ethnic and economic groups. Further, type of insurance affects screening utilization. Expanding coverage of adequate insurance can increase screening rates, as can programs that provide free (or low-cost) cancer screening to underserved populations. McCoy et al. ${ }^{21}$ and others have shown that such programs can lead to the diagnosis of cancer at an earlier stage among those who participate.

\section{Association Between Health Insurance and Cancer Stage at Diagnosis}

A limited number of studies have evaluated the association between insurance status and the stage at which cancers are diagnosed. The studies examining this topic included in this literature synthesis are summarized in Table 2 and are divided in to three subsections: studies using national data; those using state-specific data; and those evaluating duration of Medicaid enrollment. The last subsection reflects the constraints in evaluations of Medicaid insurance status at the time of diagnosis, as uninsured individuals diagnosed with cancer may retroactively receive Medicaid coverage. For example, the Breast and Cervical Cancer Treatment Act, effective October 1,2000 , gave states the option to provide women diagnosed with these cancers with Medicaid coverage through the National Breast and Cervical Cancer Early Detection Program (NBCCEDP). Thus, in many studies, it is not be possible to determine whether patients classified as having Medicaid coverage at the time of diagnosis were covered by Medicaid prior to diagnosis or were uninsured at diagnosis.

\section{Table 2. Summary of the literature relating to associations of insurance coverage with cancer diagnosis/stage} at diagnosis

\begin{tabular}{|c|c|c|c|c|c|c|}
\hline $\begin{array}{l}\text { Author } \\
\text { and } \\
\text { Citation } \\
\text { Number }\end{array}$ & Data & Cancer Type & Sample & $\begin{array}{l}\text { Insurance } \\
\text { Category }\end{array}$ & $\begin{array}{l}\text { Dependent } \\
\text { Variable }\end{array}$ & $\begin{array}{l}\text { Statistical } \\
\text { Analysis }\end{array}$ \\
\hline \multicolumn{7}{|c|}{ A. Studies Using National Data } \\
\hline $\begin{array}{l}\text { Chen } \\
\text { et al. }{ }^{24}\end{array}$ & $\begin{array}{l}1996-2003 \\
\text { NCDB data }\end{array}$ & $\begin{array}{l}\text { Invasive } \\
\text { oropharyngeal } \\
\text { cancer }\end{array}$ & $\begin{array}{l}\text { Adults } \\
\text { ages } 18+ \\
(\mathrm{N}=40,487)\end{array}$ & $\begin{array}{l}\text { Uninsured, } \\
\text { Medicaid, } \\
\text { Medicare ages } \\
\text { 18-64, Medicare } \\
\text { ages } 65+\text {, other } \\
\text { government, \& } \\
\text { private insurance }\end{array}$ & $\begin{array}{l}\text { Disease } \\
\text { stage at } \\
\text { diagnosis, } \\
\text { lymph node } \\
\text { stage at } \\
\text { diagnosis, } \\
\text { tumor stage } \\
\text { at diagnosis }\end{array}$ & $\begin{array}{l}\text { Multivariate } \\
\text { logistic } \\
\text { regression }\end{array}$ \\
\hline
\end{tabular}

\section{Results}

Compared with those with private insurance, patients with Medicaid or the uninsured were significantly more likely (based on multivariate regression odds ratios) to have advanced stage disease, the largest tumors (T4), and the greatest degree of lymph node involvement (N3).

\begin{tabular}{|c|c|c|c|c|c|c|c|}
\hline $\begin{array}{l}\text { Chen } \\
\text { et al. }{ }^{25}\end{array}$ & $\begin{array}{l}\text { 1996-2003 } \\
\text { NCDB data }\end{array}$ & $\begin{array}{l}\text { Invasive } \\
\text { laryngeal cancer }\end{array}$ & $\begin{array}{l}\text { Adults ages } \\
18+\end{array}$ & $\begin{array}{l}\text { Uninsured, } \\
\text { Medicaid, } \\
\text { Medicare ages } \\
\text { 18-64, Medicare } \\
\text { ages } 65+\text {, other } \\
\text { government, \& } \\
\text { private insurance }\end{array}$ & $\begin{array}{l}\text { Disease } \\
\text { stage at } \\
\text { diagnosis, } \\
\text { lymph node } \\
\text { stage at } \\
\text { diagnosis, } \\
\text { tumor stage } \\
\text { at diagnosis }\end{array}$ & $\begin{array}{l}\text { Multivariate } \\
\text { logistic } \\
\text { regression }\end{array}$ & $\begin{array}{l}\text { Compared with those with } \\
\text { private insurance, patients } \\
\text { with Medicaid or the } \\
\text { uninsured were more likely } \\
\text { to have advanced stage } \\
\text { disease. }\end{array}$ \\
\hline $\begin{array}{l}\text { Halpern } \\
\text { et al. }{ }^{22}\end{array}$ & $\begin{array}{l}1998-2003 \\
\text { NCDB data }\end{array}$ & $\begin{array}{l}\text { Invasive female } \\
\text { breast cancer }\end{array}$ & $\begin{array}{l}\text { Women } \\
\text { ages } 40+ \\
(\mathrm{N}=533,715)\end{array}$ & $\begin{array}{l}\text { Uninsured, } \\
\text { Medicaid, } \\
\text { Medicare ages } \\
\text { 18-64, Medicare } \\
\text { ages } 65+, \text { other } \\
\text { government, \& } \\
\text { private insurance }\end{array}$ & $\begin{array}{l}\text { Stage of } \\
\text { disease at } \\
\text { diagnosis }\end{array}$ & $\begin{array}{l}\text { Multivariate } \\
\text { logistic } \\
\text { regression }\end{array}$ & $\begin{array}{l}\text { Compared with privately } \\
\text { insured women, Medicaid } \\
\text { and uninsured women } \\
\text { were each } 1.5 \text { times more } \\
\text { likely to be diagnosed with } \\
\text { Stage II and } 2.5 \text { times more } \\
\text { likely to be diagnosed with } \\
\text { Stages III/IV vs. Stage I } \\
\text { disease ( } p<0.001) \text {. }\end{array}$ \\
\hline
\end{tabular}


Table 2. Summary of the literature relating to associations of insurance coverage with cancer diagnosis/stage at diagnosis (continued)

\begin{tabular}{|c|c|c|c|c|c|c|c|}
\hline $\begin{array}{l}\text { Author and } \\
\text { Citation } \\
\text { Number }\end{array}$ & Data & Cancer Type & Sample & $\begin{array}{l}\text { Insurance } \\
\text { Category }\end{array}$ & $\begin{array}{l}\text { Dependent } \\
\text { Variable }\end{array}$ & $\begin{array}{l}\text { Statistical } \\
\text { Analysis }\end{array}$ & Results \\
\hline \multicolumn{8}{|c|}{ A. Studies Using National Data (continued) } \\
\hline $\begin{array}{l}\text { Halpern et } \\
\text { al. }{ }^{23}\end{array}$ & $\begin{array}{l}1998-2004 \\
\text { NCDB data }\end{array}$ & $\begin{array}{l}\text { Female breast, } \\
\text { colorectal, } \\
\text { kidney, lung, } \\
\text { melanoma, } \\
\text { non- } \\
\text { Hodgkin's } \\
\text { lymphoma, } \\
\text { ovary, } \\
\text { pancreas, } \\
\text { prostate, } \\
\text { urinary } \\
\text { bladder, } \\
\text { uterus, \& } \\
\text { thyroid }\end{array}$ & $\begin{array}{l}\text { Men and } \\
\text { women } \\
\text { ages } 18+ \\
(\mathrm{N}=3,742,407)\end{array}$ & $\begin{array}{l}\text { Uninsured, } \\
\text { Medicaid, } \\
\text { Medicare ages } \\
\text { 18-64, Medicare } \\
\text { ages } 65+, \text { other } \\
\text { government, \& } \\
\text { private insurance }\end{array}$ & $\begin{array}{l}\text { Stage of } \\
\text { disease at } \\
\text { diagnosis }\end{array}$ & $\begin{array}{l}\text { Multivariate } \\
\text { logistic } \\
\text { regression }\end{array}$ & $\begin{array}{l}\text { Uninsured and Medicaid- } \\
\text { insured patients had } \\
\text { substantially increased } \\
\text { risks of presenting with } \\
\text { advanced-stage cancers } \\
\text { at diagnosis; these results } \\
\text { were most prominent for } \\
\text { patients who had cancers } \\
\text { that could be detected } \\
\text { early with screening tests } \\
\text { or symptom assessment } \\
\text { (i.e., breast, colorectal, } \\
\text { and lung cancers, as well } \\
\text { as melanoma). }\end{array}$ \\
\hline
\end{tabular}

\begin{tabular}{|c|c|c|c|c|c|c|c|}
\hline \multicolumn{8}{|c|}{ B. State-Specific Studies } \\
\hline $\begin{array}{l}\text { Bradley } \\
\text { et al. }{ }^{26}\end{array}$ & $\begin{array}{l}3 \text { linked } \\
\text { databases: } \\
\text { 1996-1998 } \\
\text { Michigan } \\
\text { cancer registry, } \\
\text { Medicaid } \\
\text { enrollment, } \\
\text { \& death } \\
\text { certificates }\end{array}$ & $\begin{array}{l}\text { Breast, uterine } \\
\text { cervix, lung, } \\
\text { prostate }\end{array}$ & $\begin{array}{l}\text { Men and } \\
\text { women } \\
\text { ages } 25+ \\
(\mathrm{N}=91,802 \\
\text { incident } \\
\text { cancer } \\
\text { cases with } \\
\mathrm{N}=11,552 \\
\text { deaths })\end{array}$ & $\begin{array}{l}\text { Medicaid, } \\
\text { Medicare, both, \& } \\
\text { neither }\end{array}$ & $\begin{array}{l}\text { Incidence, } \\
\text { stage at } \\
\text { diagnosis, } \\
\text { and death, } \\
\text { by cancer } \\
\text { type }\end{array}$ & $\begin{array}{l}\text { Multivariate } \\
\text { logistic } \\
\text { regression }\end{array}$ & $\begin{array}{l}\text { Later stage at diagnosis } \\
\text { for Medicaid enrollees; } \\
\text { Medicaid enrollees also } \\
\text { had greater risk of death. }\end{array}$ \\
\hline $\begin{array}{l}\text { O'Malley } \\
\text { et al. }{ }^{27}\end{array}$ & $\begin{array}{l}\text { 1996-1999 } \\
\text { California } \\
\text { Cancer } \\
\text { Registry- } \\
\text { Medicaid } \\
\text { linked file }\end{array}$ & $\begin{array}{l}\text { Invasive } \\
\text { cervical } \\
\text { cancer }\end{array}$ & $\begin{array}{l}\text { Women ages } \\
<65(\mathrm{~N}=4,682)\end{array}$ & $\begin{array}{l}\text { Medicaid \& non- } \\
\text { Medicaid }\end{array}$ & $\begin{array}{l}\text { Stage of } \\
\text { disease at } \\
\text { diagnosis }\end{array}$ & $\begin{array}{l}\text { Multivariate } \\
\text { logistic } \\
\text { regression }\end{array}$ & $\begin{array}{l}\text { Compared with women } \\
\text { without Medicaid } \\
\text { coverage, women } \\
\text { diagnosed during their } \\
\text { first month of Medicaid } \\
\text { enrollment had } 2.8 \text { times } \\
\text { higher odds for late- } \\
\text { stage diagnosis; women } \\
\text { who were intermittently } \\
\text { enrolled in Medicaid } \\
\text { before diagnosis had } 1.3 \\
\text { times higher odds for } \\
\text { late-stage diagnosis. }\end{array}$ \\
\hline Hahn et al. ${ }^{29}$ & $\begin{array}{l}\text { 1990-1992 } \\
\text { population- } \\
\text { based } \\
\text { case-control } \\
\text { study data, } \\
\text { metropolitan } \\
\text { Atlanta }\end{array}$ & $\begin{array}{l}\text { Invasive } \\
\text { female breast } \\
\text { cancer }\end{array}$ & $\begin{array}{l}\text { White and } \\
\text { African- } \\
\text { American } \\
\text { women } \\
\text { ages 20-54 } \\
(\mathrm{N}=829)\end{array}$ & $\begin{array}{l}\text { Private, } \\
\text { government } \\
\text { (Medicare/ } \\
\text { Medicaid), none, } \\
\text { unknown }\end{array}$ & $\begin{array}{l}\text { Disease } \\
\text { stage at } \\
\text { diagnosis } \\
\text { (I vs. IIA, I } \\
\text { vs. IIB, I vs. } \\
\text { III/IV) }\end{array}$ & $\begin{array}{l}\text { Univariate, } \\
\text { polytomous, } \\
\text { and multiple } \\
\text { logistic } \\
\text { regression }\end{array}$ & $\begin{array}{l}\text { Insurance status was } \\
\text { a significant predictor } \\
\text { of higher stage at } \\
\text { diagnosis in univariate } \\
\text { but not multiple logistic } \\
\text { regression models. } \\
\text { However, results } \\
\text { suggested that racial } \\
\text { differences in stage were } \\
\text { explained in part by } \\
\text { insurance status. }\end{array}$ \\
\hline
\end{tabular}




\begin{tabular}{|c|c|c|c|c|c|c|c|}
\hline $\begin{array}{l}\text { Author and } \\
\text { Citation } \\
\text { Number }\end{array}$ & Data & Cancer Type & Sample & $\begin{array}{l}\text { Insurance } \\
\text { Category }\end{array}$ & $\begin{array}{l}\text { Dependent } \\
\text { Variable }\end{array}$ & $\begin{array}{l}\text { Statistical } \\
\text { Analysis }\end{array}$ & Results \\
\hline \multicolumn{8}{|c|}{ B. State-Specific Studies (continued) } \\
\hline $\begin{array}{l}\text { Roetzheim } \\
\text { et al. }{ }^{28}\end{array}$ & $\begin{array}{l}\text { Florida Cancer } \\
\text { Data System } \\
\text { linked with } \\
\text { Florida Agency } \\
\text { for Health Care } \\
\text { Administration } \\
\text { data and } \\
\text { census data }\end{array}$ & $\begin{array}{l}\text { Colorectal, } \\
\text { female breast, } \\
\text { prostate, and } \\
\text { melanoma }\end{array}$ & $\begin{array}{l}\mathrm{N}=28,237 . \\
\text { Mean age } \\
\text { ranged } \\
\text { from 62.3 } \\
\text { (melanoma) } \\
\text { to } 71.6 \\
\text { (colorectal } \\
\text { cancer) }\end{array}$ & $\begin{array}{l}\text { Medicare, } \\
\text { Medicaid, } \\
\text { commercial } \\
\text { indemnity, } \\
\text { commercial PPO, } \\
\text { commercial HMO, } \\
\text { civilian health \& } \\
\text { medical program, } \\
\text { other, and } \\
\text { uninsured }\end{array}$ & $\begin{array}{l}\text { Stage at } \\
\text { diagnosis }\end{array}$ & $\begin{array}{l}\text { Logistic } \\
\text { regression }\end{array}$ & $\begin{array}{l}\text { Increased odds of late } \\
\text { stage at diagnosis among } \\
\text { patients who were } \\
\text { uninsured or who were } \\
\text { insured by Medicaid as } \\
\text { compared with privately } \\
\text { insured individuals. }\end{array}$ \\
\hline \multicolumn{8}{|c|}{ C. Studies of Duration of Medicaid Enrollment } \\
\hline $\begin{array}{l}\text { Bradley } \\
\text { et al. }\end{array}$ & $\begin{array}{l}\text { 1997-1997 } \\
\text { Michigan } \\
\text { Cancer } \\
\text { Registry, linked } \\
\text { to 1996- } \\
1998 \text { death } \\
\text { certificate } \\
\text { and Medicaid } \\
\text { enrollment } \\
\text { data }\end{array}$ & Breast cancer & $\begin{array}{l}\text { Women } \\
\text { ages } 25+ \\
\text { with a } \\
\text { primary } \\
\text { breast } \\
\text { cancer } \\
\text { diagnosis } \\
\text { who were } \\
\text { enrolled in } \\
\text { Medicaid } \\
(\mathrm{N}=1,636)\end{array}$ & $\begin{array}{l}\text { Medicaid at } \\
\text { diagnosis, } \\
\text { Medicaid after } \\
\text { diagnosis, } \\
\text { Medicaid with } \\
\text { Medicare at } \\
\text { diagnosis }\end{array}$ & $\begin{array}{l}\text { Late stage } \\
\text { at diagnosis } \\
\text { and survival }\end{array}$ & $\begin{array}{l}\text { Multivariate } \\
\text { logistic } \\
\text { regression } \\
\text { and } \\
\text { proportional } \\
\text { hazards } \\
\text { regression }\end{array}$ & $\begin{array}{l}\text { Younger women }(<65) \\
\text { who were enrolled in } \\
\text { Medicaid after diagnosis } \\
\text { were } 1.71 \text { times more } \\
\text { likely to be diagnosed } \\
\text { with late-stage disease } \\
\text { compared with younger } \\
\text { women enrolled in } \\
\text { Medicaid before diagnosis } \\
(p \leq 0.05) \text {. }\end{array}$ \\
\hline $\begin{array}{l}\text { Bradley } \\
\text { et al. }{ }^{31}\end{array}$ & $\begin{array}{l}\text { 1996-1997 } \\
\text { Michigan } \\
\text { Cancer Registry } \\
\text { files linked } \\
\text { to Medicaid } \\
\text { enrollment files }\end{array}$ & $\begin{array}{l}\text { Breast, } \\
\text { cervical, } \\
\text { colorectal, } \\
\text { and lung } \\
\text { cancer }\end{array}$ & $\begin{array}{l}\text { Adults } \\
\text { ages 24-64 } \\
(\mathrm{N}=5,852)\end{array}$ & $\begin{array}{l}\text { Medicaid enrolled } \\
\text { before diagnosis, } \\
\text { Medicaid enrolled } \\
\text { after diagnosis, \& } \\
\text { non-Medicaid }\end{array}$ & $\begin{array}{l}\text { Cancer } \\
\text { stage at } \\
\text { diagnosis, } \\
\text { stratifying } \\
\text { by each } \\
\text { cancer type }\end{array}$ & $\begin{array}{l}\text { Multivariate } \\
\text { logistic } \\
\text { regression }\end{array}$ & $\begin{array}{l}\text { Compared with those } \\
\text { with prior Medicaid } \\
\text { enrollment, cervical, } \\
\text { colorectal, and lung } \\
\text { cancer patients with } \\
\text { later enrollment were } 2-3 \\
\text { times more likely to have } \\
\text { late stage at diagnosis } \\
\text { ( } p<0.01) \text {. Compared with } \\
\text { non-Medicaid-enrollees, } \\
\text { patients with later } \\
\text { Medicaid enrollment } \\
\text { were } 2-5 \text { times more } \\
\text { likely to have late stage at } \\
\text { diagnosis ( } p<0.01 \text { ), while } \\
\text { only breast and cervical } \\
\text { cancer patients with prior } \\
\text { Medicaid enrollment } \\
\text { were } 2 \text { times more likely } \\
\text { to have late stage at } \\
\text { diagnosis ( } p<0.01 \text { ). }\end{array}$ \\
\hline
\end{tabular}




\begin{tabular}{|c|c|c|c|c|c|c|c|}
\hline $\begin{array}{l}\text { Author and } \\
\text { Citation } \\
\text { Number }\end{array}$ & Data & Cancer Type & Sample & $\begin{array}{l}\text { Insurance } \\
\text { Category }\end{array}$ & $\begin{array}{l}\text { Dependent } \\
\text { Variable }\end{array}$ & $\begin{array}{l}\text { Statistical } \\
\text { Analysis }\end{array}$ & Results \\
\hline \multicolumn{8}{|c|}{ C. Studies of Duration of Medicaid Enrollment (continued) } \\
\hline $\begin{array}{l}\text { Bradley } \\
\text { et al. }{ }^{32}\end{array}$ & $\begin{array}{l}\text { Medicaid and } \\
\text { Medicare } \\
\text { administrative } \\
\text { data linked } \\
\text { with the 1997- } \\
2000 \text { Michigan } \\
\text { Tumor Registry }\end{array}$ & $\begin{array}{l}\text { Prostate, } \\
\text { lung, breast, } \\
\text { or colorectal } \\
\text { cancer }\end{array}$ & $\begin{array}{l}\text { Patients } \\
\text { ages } 66+ \\
(\mathrm{N}=46,109)\end{array}$ & $\begin{array}{l}\text { Medicaid } \\
\text { enrollment } 12+ \\
\text { months before } \\
\text { diagnosis, }<12 \\
\text { months before } \\
\text { diagnosis, or } \\
\text { after diagnosis \& } \\
\text { Medicare only }\end{array}$ & $\begin{array}{l}\text { Diagnosis } \\
\text { during } \\
\text { the same } \\
\text { month } \\
\text { as death, } \\
\text { invasive but } \\
\text { unknown } \\
\text { stage, and } \\
\text { regional } \\
\text { or distant } \\
\text { stage } \\
\text { disease }\end{array}$ & $\begin{array}{l}\text { Multivariate } \\
\text { logistic } \\
\text { regression }\end{array}$ & $\begin{array}{l}\text { Those enrolled in } \\
\text { Medicaid }<12 \text { months } \\
\text { before diagnosis had } \\
\text { greater odds of a breast } \\
\text { and lung cancer diagnosis } \\
\text { in the month of death } \\
\text { than the Medicare- } \\
\text { only patients. Patients } \\
\text { with enrollment before } \\
\text { diagnosis had greater } \\
\text { odds of diagnosis of } \\
\text { invasive but unknown } \\
\text { stage breast, lung, and } \\
\text { prostate cancer. Patients } \\
\text { enrolled after diagnosis } \\
\text { had greater odds of } \\
\text { diagnosis of late-stage } \\
\text { colorectal, breast, and } \\
\text { lung cancer. }\end{array}$ \\
\hline
\end{tabular}

$\mathrm{HMO}=$ health maintenance organization; $\mathrm{NCDB}=$ National Cancer Data Base; PPO = preferred provider organization

Despite limitations in being able to accurately assess Medicaid vs. uninsured status at the time of cancer diagnosis, studies have reported generally consistent findings regarding health insurance status and cancer stage at diagnosis: uninsured patients and patients with Medicaid coverage are generally diagnosed at a more advanced stage than are patients with private insurance or Medicare coverage. Four recent studies used national data to assess the relationship between stage at diagnosis and insurance status; most earlier studies used data from a single state. Additionally, several studies evaluated the impact of duration of Medicaid enrollment (before cancer diagnosis) on the likelihood of diagnosing cancer at an advanced stage. Given the possibility of retroactive Medicaid enrollment among uninsured cancer patients, these studies help to clarify the impact of being uninsured versus being enrolled in Medicaid on stage at diagnosis, and they illustrate the potential benefits of longer-term Medicaid enrollment (which may permit greater continuity of care and use of screening services).

\section{Studies Using National Data}

Four recent studies used the National Cancer Data Base (NCDB), a national hospital-based registry jointly sponsored by the American Cancer Society and the American College of Surgeons, to assess the association between insurance status and stage at diagnosis. Halpern et al. ${ }^{22}$ reported that among a population of women with invasive breast cancer, those who were uninsured or had Medicaid coverage were approximately 50 percent more likely to present with stage II versus stage I disease and were more than twice as likely to present with advanced disease (stage III/IV) as were women with private insurance.

Halpern et al. ${ }^{23}$ reported similar findings across multiple types of cancers in separate analyses of 12 cancer sites (breast [female], colorectal, kidney, lung, melanoma, non-Hodgkin lymphoma, ovary, pancreas, prostate, urinary bladder, uterus, and thyroid). In this broad analysis, patients with private insurance were more likely to be diagnosed with early stage disease than were uninsured patients or patients with Medicaid coverage. This association 
between insurance status and stage at diagnosis was most pronounced among patients diagnosed with cancers that could potentially be detected early by screening or symptom assessment (breast, colorectal, and lung cancers, and melanoma).

In a similar analysis of patients diagnosed with oropharyngeal cancer, Chen et al. ${ }^{24}$ reported that those presenting with advanced stage disease at diagnosis were significantly more likely to be uninsured or covered by Medicaid than to have private insurance. Uninsured and Medicaid patients were also more likely than those with private insurance to present with large tumors and greater degrees of lymph node involvement at diagnosis. Chen et al. ${ }^{25}$ reported similar findings for patients with laryngeal cancer: those who were uninsured or had Medicaid coverage were more likely to present with advanced disease than were those with private or Medicare coverage.

\section{State-Specific Studies}

Other studies of the association between health insurance status and cancer stage at diagnosis have provided similar results. However, these other studies have been based on small study populations, generally focusing on data from a single state. Some studies have used state cancer registries linked to Medicaid data to compare stage at diagnosis and other outcomes for patients with Medicaid coverage versus those not enrolled in Medicaid. The non-Medicaid group will likely consist mainly of individuals with private insurance (for populations younger than 65), but some proportion will be uninsured. This mixing of privately insured and uninsured patients in the control group limits the interpretation of results from such studies. However, these studies have consistently reported that Medicaid insurance is associated with more advanced stage at diagnosis than is observed in the non-Medicaid population.

Bradley et al. ${ }^{26}$ studied individuals diagnosed with cancers of the breast, uterus, cervix, lung, or prostate from the Michigan cancer registry between 1996 and 1998, comparing stage at diagnosis among Medicaid enrollees with stage among individuals not enrolled in Medicaid. Among both men and women younger than 65, for all cancers studied, Medicaid enrollees were significantly more likely than the non-Medicaid population to be diagnosed at an advanced stage. Further, among those younger than age 65, Medicaid enrollees with cancer were significantly more likely to die of cancer than were non-Medicaid individuals with cancer. The increased risk (hazard ratio) for cancer death among Medicaid enrollees ranged from an almost two-fold increased risk of death from lung cancer to a more than three-fold increased risk of death from breast cancer compared with nonMedicaid patients.

In a similar analysis, O’Malley et al. ${ }^{27}$ used a California Cancer Registry-Medicaid linked file to identify 4,682 women diagnosed with invasive cervical cancer during 1996-1999. Results from multivariate logistic regression showed 2.8 times higher odds for late-stage diagnosis among women who were diagnosed during their first month of enrollment in Medicaid and 1.3 times higher odds for late-stage diagnosis among those intermittently enrolled in Medicaid before diagnosis (i.e., enrolled at the time of diagnosis and for between 1 and 11 months during the year before the diagnosis), each compared with women without Medicaid coverage (a combined group of women with private insurance and uninsured women). Results suggest the need for more outreach to these at-risk women to ensure their access to screening services. ${ }^{27}$

Roetzheim et al. ${ }^{28}$ used information from the 1994 Florida Cancer Data System to evaluate the association between insurance status and stage at diagnosis among individuals with colon, melanoma, breast, or prostate cancers. The uninsured population had a significant increase in risk of more advanced stage at diagnosis for all types compared with individuals covered by private (commercial indemnity) insurance after adjusting for age, marital status, race, income, and comorbidities. The increased risk of advanced stage at diagnosis among uninsured individuals ranged from 1.4 for breast cancer to 2.6 for melanoma.

Hahn et al. ${ }^{29}$ used data from a previous populationbased case-control study of women residing in Cobb, Fulton, or DeKalb counties in metropolitan Atlanta, Georgia, diagnosed with invasive and in situ breast cancer between May 1, 1990, and December 31, 
1992, to evaluate factors associated with advancedstage disease at diagnosis. They analyzed 829 black (30.2 percent) and white (69.8 percent) women ages 20 to 54 with unilateral invasive breast cancer. In unadjusted analyses, the odds of advanced (stage III/IV) disease versus stage I disease among black women were almost four times those of white women. However, the authors concluded that these racial differences may be explained largely by insurance status, poverty, history of mammography, method of tumor detection, and body mass index. When controlling for these other factors (as well as age) using polytomous logistic regression, the odds of stage IIA, IIB, or III/IV breast cancer at diagnosis among black women were not statistically significantly greater than among white women. Although this finding suggests that insurance status may partially explain differences in stage at diagnosis between black and white women, insurance status was not a significant predictor of advanced stage at diagnosis in the final multivariate regression model.

\section{Studies That Include Duration of Medicaid Enrollment}

When evaluating the association between Medicaid insurance coverage and cancer outcomes, accounting for the enrollment periods of Medicaid coverage is important; that is, did patients classified as Medicaid enrollees have Medicaid coverage before cancer diagnosis or only after cancer diagnosis? In many states, uninsured patients who develop certain types of cancer may be eligible for retroactive enrollment in Medicaid; therefore, the stage at diagnosis for such patients would not necessarily correspond to the stage at diagnosis for patients enrolled in Medicaid months or years before cancer diagnosis. Most of the studies reviewed for this research report were unable to account for Medicaid enrollment periods because this information is generally not available in cancer registries and similar data sources, even when insurance status is reported. This is a considerable limitation in interpreting reported associations between cancer patients' outcomes and Medicaid coverage.

Bradley et al. ${ }^{30}$ were able to account for Medicaid enrollment periods in their analyses of 1,636 Medicaid insured women with a primary breast cancer diagnosis recorded in the Michigan Cancer
Registry during 1996-1997. Analyses were stratified into women younger than 65 years and women 65 and older. Among the younger women, those without Medicaid coverage before diagnosis (i.e., enrolled in Medicaid at the time of or after diagnosis) had significantly higher odds of late stage disease (OR = $1.71,95 \% \mathrm{CI}=1.13-2.58)$ and a significant increase in risk of death $(\mathrm{HR}=1.67,95 \% \mathrm{CI}=1.09-2.56)$ compared with those with Medicaid coverage before diagnosis. In contrast, among women age 65 or older, those with and those without Medicaid coverage before diagnosis did not differ significantly regarding stage at diagnosis and risk of death. ${ }^{30}$ This difference may reflect the availability of mammography for these two populations. Women enrolled in Medicare have coverage for mammography (as well as physician services to assess self-detected breast symptoms), regardless of whether or not they are also enrolled in Medicaid. However, while the NBCCEDP and other programs cover the costs of mammography for uninsured women, rates of mammography in this population (as discussed in the previous section on cancer screening services) are lower than those among insured women, including those with Medicaid coverage. ${ }^{8}$

In a separate study, Bradley et al. ${ }^{31}$ evaluated differences in stage at diagnosis for cancer patients enrolled in Medicaid before versus after diagnosis as well as differences between Medicaid enrollees and non-Medicaid enrollees. The study sample included all incident cases of breast, cervical, colorectal, and lung cancer from the 1996-1997 Michigan Cancer Registry files in patients who were 24 to 64 years of age at diagnosis; these cases were further linked to Medicaid enrollment files $(\mathrm{N}=5,852)$. Compared with those enrolled in Medicaid before diagnosis, cervical, colorectal, and lung cancer patients enrolled in Medicaid after diagnosis were 2 to 3 times more likely to be diagnosed with late stage disease $(p<$ 0.01 for each). Cancer patients enrolled in Medicaid after diagnosis were 2 to 5 times more likely to be diagnosed with late stage disease $(p<0.01$ for each of the four cancer sites) than were cancer patients not enrolled in Medicaid (i.e., combined patients with private insurance or uninsured). In contrast, among cancer patients enrolled in Medicaid before diagnosis, only breast and cervical cancer patients were 
significantly more likely to be diagnosed with late stage disease ( $p<0.01$ for each) than were patients not enrolled in Medicaid.

In a recent study, Bradley et al. ${ }^{32}$ examined the relationship between advanced cancer at diagnosis and Medicaid enrollment in patients ages 66 and older using Medicaid and Medicare administrative data linked with the Michigan Tumor Registry. The study sample included 46,109 patients diagnosed during 1997-2000 with prostate, lung, breast, or colorectal cancer as their first primary cancer. Medicaid enrollment status was categorized as being enrolled 12 or more $(>12)$ months before diagnosis, less than $12(<12)$ months before diagnosis, after diagnosis, or not enrolled in Medicaid (i.e., Medicare only, which was the referent group in each analysis).

As essentially all patients in this study had Medicare coverage at the time of diagnosis, Medicaid enrollment reflects the patient's economic status rather than a new coverage based on a cancer diagnosis. For this study population, Medicaid enrollment before diagnosis indicates a lower income than that of patients not enrolled in Medicaid; Medicaid enrollment after diagnosis suggests a decrease in income following diagnosis, potentially because of patient-borne costs of cancer treatment.

All patients enrolled in Medicaid before diagnosis had a higher likelihood than Medicare-only patients of the following outcomes: death during the same month as diagnosis (lung cancer patients in the $>12$ and $<12$ months enrollment groups and breast cancer patients in the $<12$ months group); diagnosis with invasive but unknown stage (lung cancer patients in the $>12$ and $<12$ months enrollment groups, breast cancer patients in the $<12$ months group, and prostate cancer patients in the $\geq 12$ months group); and regional or distant stage at diagnosis (lung cancer patients in the $<12$ months group). Both lung and breast cancer patients enrolled in Medicaid after diagnosis were more likely than Medicare only patients (i.e., not enrolled in Medicaid) to have regional or distant stage disease at diagnosis, which (in general) is associated with greater treatment costs than is early stage disease. Based on these results, the authors concluded that advanced stage cancer tends to precipitate Medicaid enrollment. ${ }^{32}$ It may also be concluded that
Medicaid enrollment (and thus lower income) before cancer diagnosis is associated with increased risk of advanced stage diagnosis and death.

Overall, the reviewed studies that included duration of Medicaid enrollment indicate that individuals younger than 65 who are not enrolled in Medicaid until the time of cancer diagnosis are more likely to be diagnosed with later stage disease than are those who enroll in Medicaid before diagnosis. In contrast, these studies also indicate that among individuals age 65 and older, the presence of or duration of Medicaid enrollment before diagnosis may not affect the likelihood of advanced disease.

The studies included in this section on insurance status and stage at diagnosis, while limited in their ability to control for individual socioeconomic status and other individual-level characteristics, provide population-based evidence of more advanced cancer stages at diagnosis among populations that are uninsured or have Medicaid insurance. The lower rates of utilization for cancer screening services among uninsured adults, discussed in the first section of this report, may be the principal reason for diagnosis at more advanced stages of cancer than among insured adults.

Information on rates of cancer screening among Medicaid patients compared with patients with private insurance is very limited, so it is difficult to link cancer screening behaviors to increased likelihood of advanced disease for the Medicaid population. In addition, significant associations have been observed between being uninsured or having Medicaid coverage and being diagnosed with lung cancer at a more advanced stage; lung cancer is not normally detected early by screening. Thus, the relationship between being uninsured or covered by Medicaid and advanced stage at diagnosis goes beyond the impact of screening rates.

Multiple factors associated with Medicaid status and being uninsured (including race/ethnicity, socioeconomic status, health practices and beliefs, and having a usual source of care or a medical home) are likely associated with decreased access to care (e.g., resulting in delays in follow-up care) and decreased quality of care, leading to increased risk of advanced disease at diagnosis. 


\section{Association Between Health Insurance and Cancer Treatment Patterns or Outcomes}

Studies of the relationship between health insurance status and either cancer treatment patterns (i.e., the type of treatment received) or cancer outcomes (mainly survival) are summarized in Table 3.

\section{Studies of Health Insurance and Cancer Treatment Patterns}

A small number of studies have analyzed associations between insurance coverage and cancer treatment using data from a single institution, single state, or group of states; the evidence from these studies is mixed. Among nine studies included, five found that uninsured or Medicaid patients were less likely than privately insured patients to receive guideline therapies.33-37 Mitchell et al., ${ }^{33}$ using 1988 and 1991 hospital discharge data from four states, found that leukemia and lymphoma patients (1) enrolled in Medicaid, (2) uninsured, or (3) in HMOs were less likely than their counterparts enrolled in private FFS insurance plans to receive bone marrow transplantation.

Roetzheim et al. ${ }^{34}$ studied women younger than 65 diagnosed with early stage breast cancer in Florida during 1994. These researchers reported that women who were uninsured or insured by Medicaid had lower utilization of radiotherapy after breastconserving surgery than did privately insured women. A separate study by Roetzheim et al. using 1994 Florida data ${ }^{35}$ found that uninsured or Medicaidinsured colorectal cancer patients had lower utilization of guideline therapies than did privately insured patients.

Voti et al. ${ }^{36}$ studied receipt of "standard treatment" (i.e., guideline-approved therapy) among Florida resident women diagnosed with local stage breast cancer between July 1997 and December 2000 $(\mathrm{N}=26,423)$. Standard treatment was defined as mastectomy or breast-conserving surgery followed by radiation therapy. Compared with privately insured patients, those with Medicare were 1.36 times more likely (95\% CI $=1.22-1.51)$ to receive standard treatment. In contrast, patients with Medicaid were 0.71 times as likely (95\% CI $=0.53-0.96)$, and uninsured patients were 0.76 times as likely $(95 \% \mathrm{CI}=$ 0.59-0.96) to receive the standard treatment.

Bradley et al. ${ }^{37}$ used data from the Metropolitan Detroit SEER (Surveillance, Epidemiology and End Results) registry to identify women diagnosed with breast cancer during 1996-1997 ( $\mathrm{N}=5,719)$, then linked these records to Michigan Medicaid enrollment files to identify patients with Medicaid coverage. Compared with women who were not Medicaidinsured (which, as discussed above, likely includes a mix of privately insured and uninsured patients), women with Medicaid coverage (either HMO or FFS) had significantly greater odds of being diagnosed at a later stage; no significant difference in odds of having had breast-conserving surgery alone; and significantly decreased odds of having had breastconserving surgery with radiation. In addition, women with Medicaid FFS plans had significantly greater odds of having died as a result of their breast cancer $(\mathrm{OR}=3.11,95 \% \mathrm{CI}=2.19-4.42)$; the risk for death was not significantly different for the Medicaid HMO population.

In contrast, three other studies reported no significant association between insurance status and cancer treatment patterns, and one study reported a significantly negative association. ${ }^{38-41}$ Analyzing pattern of surgery among early-stage breast cancer patients treated at a single institution from 1993-2000, Parviz et al. ${ }^{38}$ found no association between insurance coverage and surgery treatment pattern. Harlan et al. ${ }^{39}$ studied 11 types of cancer in the 1995-1999 National Cancer Institute Patterns of Care Study and found that lack of insurance had only a weak impact on the receipt of guideline treatments. Adherence to guidelines is a broad measure and may not be sensitive enough to pick up differences in care associated with insurance status in this population. In a small study population ( $\mathrm{N}=303)$ using 2001 Louisiana Cancer Registry data, Wu et al. ${ }^{40}$ did not find a significant association of postoperative chemotherapy with insurance coverage among stage III colon cancer patients. In one study reporting a negative association, Richardson et al. ${ }^{41}$ found that uninsured and Medicaid breast cancer patients in Florida were more likely to receive chemotherapy than were privately insured and Medicare patients among those diagnosed in nonteaching hospitals from 1997-2000. 


\section{Table 3. Summary of the literature relating to associations of insurance coverage with cancer treatment and cancer outcomes}

\begin{tabular}{|c|c|c|c|c|c|c|c|}
\hline $\begin{array}{l}\text { Author } \\
\text { and } \\
\text { Citation } \\
\text { Number }\end{array}$ & Data & $\begin{array}{l}\text { Cancer } \\
\text { Type }\end{array}$ & Sample & $\begin{array}{l}\text { Insurance } \\
\text { Category }\end{array}$ & $\begin{array}{l}\text { Dependent } \\
\text { Variable }\end{array}$ & $\begin{array}{l}\text { Statistical } \\
\text { Analysis }\end{array}$ & Results \\
\hline \multicolumn{8}{|c|}{ A. Studies of Insurance Status and Cancer Treatment } \\
\hline $\begin{array}{l}\text { Bradley } \\
\text { et al. }{ }^{37}\end{array}$ & $\begin{array}{l}\text { 1996-1997 } \\
\text { Metropolitan } \\
\text { Detroit SEER } \\
\text { registry } \\
\text { linked to } \\
\text { Michigan } \\
\text { Medicaid } \\
\text { enrollment } \\
\text { files }\end{array}$ & $\begin{array}{l}\text { Female } \\
\text { breast } \\
\text { cancer }\end{array}$ & $(\mathrm{N}=5,719)$ & $\begin{array}{l}\text { Medicaid HMO, } \\
\text { Medicaid FFS, \& } \\
\text { non-Medicaid }\end{array}$ & $\begin{array}{l}\text { Late stage } \\
\text { at diagnosis, } \\
\text { breast- } \\
\text { conserving } \\
\text { surgery, breast- } \\
\text { conserving } \\
\text { surgery with } \\
\text { radiation, no } \\
\text { surgery, and } \\
\text { death }\end{array}$ & $\begin{array}{l}\text { Multivariate } \\
\text { logistic } \\
\text { regression }\end{array}$ & $\begin{array}{l}\text { Compared with the non-Medicaid- } \\
\text { insured, women with Medicaid HMO } \\
\text { plans were more likely to have later } \\
\text { stage at diagnosis, equally likely to } \\
\text { have BCS alone, less likely to have } \\
\text { BCS with radiation, and equal in } \\
\text { likelihood of survival; while women } \\
\text { with Medicaid FFS plans were } \\
\text { more likely to have later stage at } \\
\text { diagnosis, equally likely to have BCS } \\
\text { alone, less likely to have BCS with } \\
\text { radiation, and more likely to die. }\end{array}$ \\
\hline $\begin{array}{l}\text { Harlan } \\
\text { et al. }\end{array}$ & $\begin{array}{l}\text { 1995-1999 } \\
\text { NCI Patterns } \\
\text { of Care } \\
\text { study (newly } \\
\text { diagnosed } \\
\text { cancers) }\end{array}$ & $\begin{array}{l}11 \text { types } \\
\text { of cancer } \\
\text { (aggregate } \\
\text { analysis) }\end{array}$ & $\begin{array}{l}\text { Adults } \\
\text { ages } 20+ \\
(\mathrm{N}=7,134)\end{array}$ & $\begin{array}{l}\text { Uninsured, } \\
\text { Medicaid, } \\
\text { private, } \\
\text { Medicare, \& } \\
\text { other }\end{array}$ & $\begin{array}{l}\text { Guideline } \\
\text { therapy }\end{array}$ & $\begin{array}{l}\text { Bivariate and } \\
\text { multivariate } \\
\text { analysis }\end{array}$ & $\begin{array}{l}\text { Patients with no insurance or private } \\
\text { insurance were significantly more } \\
\text { likely to receive guideline therapy } \\
\text { than patients with Medicare and } \\
\text { Medicaid. }\end{array}$ \\
\hline $\begin{array}{l}\text { Mitchell } \\
\text { et al. }{ }^{33}\end{array}$ & $\begin{array}{l}1988 \text { and } \\
1991 \\
\text { inpatient } \\
\text { hospital } \\
\text { discharge } \\
\text { data from } 4 \\
\text { states }\end{array}$ & $\begin{array}{l}\text { Leukemia } \\
\text { and } \\
\text { lymphoma }\end{array}$ & $\begin{array}{l}\text { Adults } \\
\text { ages }<65 \\
(\mathrm{~N}=38,420)\end{array}$ & $\begin{array}{l}\text { Private } \\
\text { commercial, } \\
\text { Medicaid, HMO, } \\
\text { uninsured, \& } \\
\text { other }\end{array}$ & BMT & $\begin{array}{l}\text { Multivariate } \\
\text { logistic } \\
\text { regression }\end{array}$ & $\begin{array}{l}\text { Medicaid, uninsured, and HMO } \\
\text { patients are significantly less likely } \\
\text { than privately insured patients to } \\
\text { receive a BMT. }\end{array}$ \\
\hline $\begin{array}{l}\text { Parviz } \\
\text { et al. }{ }^{38}\end{array}$ & $\begin{array}{l}1993-2000 \\
\text { single } \\
\text { institute } \\
\text { chart review }\end{array}$ & $\begin{array}{l}\text { Breast } \\
\text { cancer, } \\
\text { stage 0-II }\end{array}$ & $\begin{array}{l}\text { All ages } \\
(\mathrm{N}=928)\end{array}$ & $\begin{array}{l}\text { Uninsured, } \\
\text { Medicaid, } \\
\text { private, \& } \\
\text { Medicare }\end{array}$ & $\begin{array}{l}\text { Treatment: BCS } \\
\text { vs. mastectomy }\end{array}$ & $\begin{array}{l}\text { Pearson } \\
\text { chi-square, } \\
\text { logistic } \\
\text { regression, } \\
\text { t-test }\end{array}$ & $\begin{array}{l}624 \text { of } 928 \text { had BCS; insurance status } \\
\text { was not associated with type of } \\
\text { surgery (not based on regression } \\
\text { analysis). }\end{array}$ \\
\hline $\begin{array}{l}\text { Richardson } \\
\text { et al. }{ }^{41}\end{array}$ & $\begin{array}{l}1997-2000 \\
\text { Florida } \\
\text { cancer } \\
\text { registry }\end{array}$ & $\begin{array}{l}\text { Breast } \\
\text { cancer }\end{array}$ & $\begin{array}{l}\text { All ages } \\
(\mathrm{N}=11,175)\end{array}$ & $\begin{array}{l}\text { Uninsured, } \\
\text { Medicaid, } \\
\text { Medicare, } \\
\text { \& privately } \\
\text { insured }\end{array}$ & $\begin{array}{l}\text { Adjuvant } \\
\text { chemotherapy } \\
\text { for patients with } \\
\text { regional-stage } \\
\text { disease }\end{array}$ & $\begin{array}{l}\text { Multivariate } \\
\text { logistic } \\
\text { regression }\end{array}$ & $\begin{array}{l}\text { Uninsured and Medicaid patients } \\
\text { were significantly more likely to } \\
\text { receive chemotherapy than privately } \\
\text { insured and Medicare patients. }\end{array}$ \\
\hline $\begin{array}{l}\text { Roetzheim } \\
\text { et al. }{ }^{34}\end{array}$ & $\begin{array}{l}1994 \text { Florida } \\
\text { cancer } \\
\text { registry, } \\
\text { followed } \\
\text { through } \\
1997\end{array}$ & $\begin{array}{l}\text { Stages } \\
\text { I and II } \\
\text { breast } \\
\text { cancer }\end{array}$ & $\begin{array}{l}\text { Adults } \\
\text { ages }<65 \\
(\mathrm{~N}=9,551)\end{array}$ & $\begin{array}{l}\text { Uninsured, } \\
\text { Medicaid, } \\
\text { Medicare, } \\
\text { Medicare HMO, } \\
\text { commercial } \\
\text { indemnity, } \\
\text { commercial } \\
\text { HMO/PPO, \& } \\
\text { other }\end{array}$ & $\begin{array}{l}\text { Survival and } \\
\mathrm{BCS} \text { with } \\
\text { radiotherapy }\end{array}$ & $\begin{array}{l}\text { Multivariate } \\
\text { logistic and } \\
\text { survival } \\
\text { analyses }\end{array}$ & $\begin{array}{l}\text { Uninsured patients were less likely } \\
\text { to receive BCS than privately insured } \\
\text { patients. Among patients receiving } \\
\mathrm{BCS} \text {, insurance was not significantly } \\
\text { associated with use of radiation } \\
\text { therapy. In addition, insurance was } \\
\text { also not associated with survival. }\end{array}$ \\
\hline $\begin{array}{l}\text { Roetzheim } \\
\text { et al. }{ }^{35}\end{array}$ & $\begin{array}{l}1994 \text { Florida } \\
\text { cancer } \\
\text { registry, } \\
\text { followed } \\
\text { through } \\
1997\end{array}$ & $\begin{array}{l}\text { Colorectal } \\
\text { cancer }\end{array}$ & $\begin{array}{l}\text { All ages } \\
(\mathrm{N}=11,113)\end{array}$ & $\begin{array}{l}\text { Uninsured, } \\
\text { Medicare FFS, } \\
\text { Medicare HMO, } \\
\text { commercial } \\
\text { HMO, } \\
\text { commercial } \\
\text { FFS, \& others }\end{array}$ & $\begin{array}{l}\text { Treatment } \\
\text { (surgery, } \\
\text { radiation, or } \\
\text { chemotherapy) } \\
\text { and survival }\end{array}$ & $\begin{array}{l}\text { Multivariate } \\
\text { logistic and } \\
\text { survival (Cox } \\
\text { proportional } \\
\text { hazards) } \\
\text { models }\end{array}$ & $\begin{array}{l}\text { Medicaid and uninsured patients } \\
\text { were less likely than privately } \\
\text { insured patients to receive surgery } \\
\text { treatment, but not radiotherapy } \\
\text { or chemotherapy; Medicaid and } \\
\text { uninsured patients had lower } \\
\text { survival rates than privately insured } \\
\text { patients. }\end{array}$ \\
\hline
\end{tabular}




\section{Table 3. Summary of the literature relating to associations of insurance coverage with cancer treatment and cancer outcomes (continued)}

\begin{tabular}{|c|c|c|c|c|c|c|c|}
\hline $\begin{array}{l}\text { Author } \\
\text { and } \\
\text { Citation } \\
\text { Number }\end{array}$ & Data & Cancer Type & Sample & $\begin{array}{l}\text { Insurance } \\
\text { Category }\end{array}$ & $\begin{array}{l}\text { Dependent } \\
\text { Variable }\end{array}$ & $\begin{array}{l}\text { Statistical } \\
\text { Analysis }\end{array}$ & Results \\
\hline \multicolumn{8}{|c|}{ A. Studies of Insurance Status and Cancer Treatment (continued) } \\
\hline $\begin{array}{l}\text { Voti } \\
\text { et al. }{ }^{36}\end{array}$ & $\begin{array}{l}\text { July } 1997 \text { - } \\
\text { December } \\
2000 \text { Florida } \\
\text { cancer registry } \\
\text { linked to } \\
\text { Florida Agency } \\
\text { for Health Care } \\
\text { Administration } \\
\text { databases }\end{array}$ & $\begin{array}{l}\text { Local stage } \\
\text { female breast } \\
\text { cancers }\end{array}$ & $(\mathrm{N}=23,817)$ & $\begin{array}{l}\text { Uninsured, } \\
\text { private } \\
\text { insurance, } \\
\text { Medicare, \& } \\
\text { Medicaid }\end{array}$ & $\begin{array}{l}\text { Receipt of } \\
\text { mastectomy or } \\
\text { BCS followed } \\
\text { by radiation } \\
\text { therapy }\end{array}$ & $\begin{array}{l}\text { Multivariate } \\
\text { logistic } \\
\text { regression }\end{array}$ & $\begin{array}{l}\text { Compared with privately } \\
\text { insured patients, those with } \\
\text { Medicare were } 1.36 \text { times } \\
\text { more likely }(95 \% \mathrm{Cl}=1.22- \\
1.51) \text {, those with Medicaid } \\
\text { were } 0.71 \text { times as likely } \\
(95 \% \mathrm{Cl}=0.53-0.96) \text {, and } \\
\text { uninsured patients were } \\
0.76 \text { times as likely ( } 95 \% \\
\mathrm{Cl}=0.59-0.96) \text { to receive the } \\
\text { standard treatment. }\end{array}$ \\
\hline
\end{tabular}

\begin{tabular}{|c|c|c|c|c|c|c|c|}
\hline $\begin{array}{l}\text { Wu } \\
\text { et al. }{ }^{40}\end{array}$ & $\begin{array}{l}2001 \text { Los } \\
\text { Angeles cancer } \\
\text { registry }\end{array}$ & $\begin{array}{l}\text { Stage III colon } \\
\text { cancer }\end{array}$ & $\begin{array}{l}\text { Adults } \\
\text { ages } 20+ \\
(\mathrm{N}=303)\end{array}$ & $\begin{array}{l}\text { Private \& } \\
\text { public/ } \\
\text { uninsured }\end{array}$ & $\begin{array}{l}\text { Postoperative } \\
\text { chemotherapy }\end{array}$ & $\begin{array}{l}\text { Univariate and } \\
\text { multivariate } \\
\text { logistics } \\
\text { regression }\end{array}$ & $\begin{array}{l}\text { Neither univariate nor } \\
\text { multivariate analyses found } \\
\text { statistically significant } \\
\text { associations of insurance } \\
\text { coverage and post-operative } \\
\text { chemotherapy. }\end{array}$ \\
\hline \multicolumn{8}{|c|}{ B. Studies of Insurance Status and Cancer Outcomes } \\
\hline $\begin{array}{l}\text { Allareddy } \\
\& \\
\text { Konety } 45\end{array}$ & $\begin{array}{l}2000-2003 \\
\text { Nationwide } \\
\text { Inpatient } \\
\text { Sample }\end{array}$ & $\begin{array}{l}\text { Patients with } \\
\text { a primary } \\
\text { diagnosis of } \\
\text { head and neck } \\
\text { cancer }\end{array}$ & $(\mathrm{N}=24,803)$ & $\begin{array}{l}\text { Medicare, } \\
\text { Medicaid, self- } \\
\text { pay/no charge/ } \\
\text { other, \& private }\end{array}$ & $\begin{array}{l}\text { In-hospital } \\
\text { mortality after } \\
\text { hospitalizations } \\
\text { for head and } \\
\text { neck cancer }\end{array}$ & $\begin{array}{l}\text { Multivariate } \\
\text { logistic } \\
\text { regression }\end{array}$ & $\begin{array}{l}\text { Patients who were self-pay/ } \\
\text { no charge/other had } 1.42 \\
(p<0.01) \text { greater odds of in- } \\
\text { hospital mortality compared } \\
\text { with patients with private } \\
\text { insurance. }\end{array}$ \\
\hline $\begin{array}{l}\text { Bradley } \\
\text { et al. }{ }^{30}\end{array}$ & $\begin{array}{l}\text { 1997-1997 } \\
\text { Michigan } \\
\text { Cancer } \\
\text { Registry, linked } \\
\text { to 1996- } \\
1998 \text { death } \\
\text { certificate } \\
\text { and Medicaid } \\
\text { enrollment } \\
\text { data }\end{array}$ & Breast cancer & $\begin{array}{l}\text { Women } \\
\text { ages } 25+ \\
\text { w/ primary } \\
\text { breast } \\
\text { cancer } \\
\text { diagnosis } \\
\text { who were } \\
\text { enrolled in } \\
\text { Medicaid } \\
(\mathrm{N}=1,636)\end{array}$ & $\begin{array}{l}\text { Medicaid } \\
\text { during month } \\
\text { of diagnosis, } \\
\text { Medicaid } \\
\text { after month } \\
\text { of diagnosis, } \\
\text { Medicare } \\
\text { with Medicaid } \\
\text { during month } \\
\text { of diagnosis }\end{array}$ & $\begin{array}{l}\text { Late stage at } \\
\text { diagnosis and } \\
\text { survival }\end{array}$ & $\begin{array}{l}\text { Multivariate } \\
\text { logistic } \\
\text { regression and } \\
\text { proportional } \\
\text { hazards } \\
\text { regression }\end{array}$ & $\begin{array}{l}\text { Younger women (ages <65) } \\
\text { who were not enrolled in } \\
\text { Medicaid after diagnosis had } \\
\text { a } 1.67 \text {-fold increase in risk } \\
\text { of death from the disease } \\
\text { compared with younger } \\
\text { women enrolled in Medicaid } \\
\text { before diagnosis }(p \leq 0.05) \text {. }\end{array}$ \\
\hline $\begin{array}{l}\text { Bradley } \\
\text { et al. } 43\end{array}$ & $\begin{array}{l}\text { 1996-1997 } \\
\text { Michigan } \\
\text { Tumor Registry } \\
\text { data linked } \\
\text { to Medicaid } \\
\text { enrollment } \\
\text { files }\end{array}$ & $\begin{array}{l}\text { Breast, } \\
\text { colorectal, and } \\
\text { lung cancer }\end{array}$ & $\begin{array}{l}\text { Adults } \\
\text { ages <65 } \\
(\mathrm{N}=13,740)\end{array}$ & $\begin{array}{l}\text { Medicaid } \\
\text { enrollment } \\
12+\text { months } \\
\text { before } \\
\text { diagnosis, }<12 \\
\text { months before } \\
\text { diagnosis, \& } \\
\text { non-Medicaid }\end{array}$ & $\begin{array}{l}\text { Survival } \\
\text { stratified by } \\
\text { cancer type, } \\
\text { stage at } \\
\text { diagnosis (early } \\
\text { or late), and } \\
\text { gender }\end{array}$ & $\begin{array}{l}\text { Multivariate } \\
\text { Cox } \\
\text { proportional } \\
\text { hazards } \\
\text { regression } \\
\text { analyses }\end{array}$ & $\begin{array}{l}\text { The risk of death for both } \\
\text { groups of Medicaid patients } \\
\text { was nearly } 2 \text { to } 3 \text { times } \\
\text { greater ( } p<0.05 \text { ) than for } \\
\text { non-Medicaid patients, over } \\
\text { all type, stage, and gender } \\
\text { strata. However, the risk of } \\
\text { death was not significantly } \\
\text { different between the } \\
\text { enrolled and the late- } \\
\text { enrolled Medicaid patients. }\end{array}$ \\
\hline $\begin{array}{l}\text { Kelz } \\
\text { et al. }{ }^{44}\end{array}$ & $\begin{array}{l}1997-98 \\
\text { hospitalized } \\
\text { patients in } \\
\text { Nationwide } \\
\text { Inpatient } \\
\text { Sample }\end{array}$ & $\begin{array}{l}\text { Nonrecurrent, } \\
\text { nonmetastatic } \\
\text { colorectal } \\
\text { carcinoma }\end{array}$ & $\begin{array}{l}\text { Adults } \\
\text { ages 40-64 } \\
(\mathrm{N}=13,415)\end{array}$ & $\begin{array}{l}\text { Uninsured, } \\
\text { private } \\
\text { insurance, \& } \\
\text { Medicaid }\end{array}$ & $\begin{array}{l}\text { Postoperative } \\
\text { complications } \\
\text { and in-hospital } \\
\text { mortality }\end{array}$ & $\begin{array}{l}\text { Multivariate } \\
\text { logistic } \\
\text { regression }\end{array}$ & $\begin{array}{l}\text { Only Medicaid patients } \\
\text { were more likely to have } \\
\text { complications and death } \\
\text { in hospitals than privately } \\
\text { insured patients. }\end{array}$ \\
\hline
\end{tabular}




\begin{tabular}{|c|c|c|c|c|c|c|c|}
\hline $\begin{array}{l}\text { Author } \\
\text { and } \\
\text { Citation } \\
\text { Number }\end{array}$ & Data & $\begin{array}{l}\text { Cancer } \\
\text { Type }\end{array}$ & Sample & $\begin{array}{l}\text { Insurance } \\
\text { Category }\end{array}$ & $\begin{array}{l}\text { Dependent } \\
\text { Variable }\end{array}$ & $\begin{array}{l}\text { Statistical } \\
\text { Analysis }\end{array}$ & Results \\
\hline \multicolumn{8}{|c|}{ B. Studies of Insurance Status and Cancer Outcomes (continued) } \\
\hline $\begin{array}{l}\text { Kirsner } \\
\text { et al. }{ }^{46}\end{array}$ & $\begin{array}{l}\text { 1985-2001 } \\
\text { SEER- } \\
\text { Medicare } \\
\text { data }\end{array}$ & $\begin{array}{l}\text { Incident } \\
\text { female } \\
\text { breast and } \\
\text { colorectal } \\
\text { cancer }\end{array}$ & $\begin{array}{l}\text { Adults } \\
\text { ages } \\
65+\text { and } \\
\text { entitled to } \\
\text { Medicare } \\
\text { part A and } \\
\text { part B }\end{array}$ & $\begin{array}{l}\text { Medicare HMO } \\
\text { \& Medicare FFS }\end{array}$ & $\begin{array}{l}\text { Overall and } \\
\text { cancer-stage- } \\
\text { specific } \\
\text { survival }\end{array}$ & $\begin{array}{l}\text { Multivariate } \\
\text { Cox } \\
\text { proportional } \\
\text { hazards } \\
\text { regression } \\
\text { models }\end{array}$ & $\begin{array}{l}\text { HMO Medicare patients had } \\
\text { significantly improved survival } \\
\text { for both breast cancer }(\mathrm{HR}=0.91 \text {, } \\
95 \% \mathrm{Cl}=0.88-0.93 \text { ) and colorectal } \\
\text { cancer }(\mathrm{HR}=0.94,95 \% \mathrm{Cl}=0.92- \\
\text { 0.97) compared with } \mathrm{FFS} \text { Medicare } \\
\text { patients. }\end{array}$ \\
\hline $\begin{array}{l}\text { McDavid } \\
\text { et al. } 42\end{array}$ & $\begin{array}{l}\text { 1995-98 } \\
\text { Kentucky } \\
\text { Cancer } \\
\text { Registry, } \\
\text { followed } \\
\text { until } 1999\end{array}$ & $\begin{array}{l}\text { Breast, } \\
\text { lung, } \\
\text { colorectal, } \\
\text { prostate }\end{array}$ & $\begin{array}{l}\text { Adults } \\
\text { ages } 18-99 \\
(\mathrm{~N}=40,207)\end{array}$ & $\begin{array}{l}\text { Private, } \\
\text { Medicare with } \\
\text { supplement, } \\
\text { Medicare, } \\
\text { other federally } \\
\text { funded, } \\
\text { Medicaid/ } \\
\text { welfare, } \\
\text { uninsured, \& } \\
\text { unknown }\end{array}$ & Death & $\begin{array}{l}\text { Chi-squared } \\
\text { test, poisson } \\
\text { regression }\end{array}$ & $\begin{array}{l}\text { Among prostate cancer, } 3 \text {-yr } \\
\text { survival was } 98 \% \text { for the privately } \\
\text { insured and } 83 \% \text { for the uninsured; } \\
\text { results were } 91 \% \text { and } 78 \% \text { for } \\
\text { breast cancer, } 71 \% \text { and } 53 \% \text { for } \\
\text { colorectal cancer, and } 23 \% \text { and } \\
13 \% \text { for lung cancer; in regression } \\
\text { analyses, Medicaid patients had } \\
\text { worse survival than privately } \\
\text { insured patients for all } 4 \text { cancers, } \\
\text { and uninsured patients had worse } \\
\text { survival than privately insured } \\
\text { patients in lung and breast cancers. }\end{array}$ \\
\hline $\begin{array}{l}\text { Okunade } \\
\text { et al. } 47\end{array}$ & $\begin{array}{l}\text { 1990-1997 } \\
\text { time-series } \\
\text { data pooled } \\
\text { across the } \\
\text { US }\end{array}$ & $\begin{array}{l}\text { Breast } \\
\text { cancer }\end{array}$ & $\begin{array}{l}\text { Adults } \\
\text { ages } 25+\end{array}$ & $\begin{array}{l}\text { Medicaid, } \\
\text { Medicare, \& } \\
\text { uninsured }\end{array}$ & $\begin{array}{l}\text { Breast cancer } \\
\text { mortality rate } \\
\text { (per } 100,000 \\
\text { female } \\
\text { population) }\end{array}$ & $\begin{array}{l}\text { State fixed } \\
\text { effects with } \\
\text { multivariate } \\
\text { GLS regression }\end{array}$ & $\begin{array}{l}\text { Higher } \% \text { uninsured or Medicaid } \\
\text { population was associated with } \\
\text { higher mortality rates. }\end{array}$ \\
\hline $\begin{array}{l}\text { Penson } \\
\text { et al. }{ }^{48}\end{array}$ & $\begin{array}{l}1995-1998 \\
\text { CaPSURE } \\
\text { database } \\
\text { from } 25 \\
\text { community } \\
\text { and } 1 \\
\text { academic } \\
\text { urologic } \\
\text { practice }\end{array}$ & $\begin{array}{l}\text { Prostate } \\
\text { cancer }\end{array}$ & $\begin{array}{l}\text { All ages } \\
(\mathrm{N}=860)\end{array}$ & $\begin{array}{l}\text { Medicare, } \\
\text { Medicare/ } \\
\text { Medigap, PPO, } \\
\text { HMO, FFS, \& } \\
\text { uninsured }\end{array}$ & $\begin{array}{l}\text { HRQOL } \\
\text { (measured } \\
\text { by SF-36 and } \\
\text { UCLA Prostate } \\
\text { Cancer Index) }\end{array}$ & $\begin{array}{l}\text { Multivariate } \\
\text { mixed } \\
\text { (longitudinal) } \\
\text { regression } \\
\text { analyses }\end{array}$ & $\begin{array}{l}\text { In comparison to HMO patients, } \\
\text { uninsured patients generally } \\
\text { had lower HRQOL; there was } \\
\text { no difference in HRQOL among } \\
\text { insured patients. }\end{array}$ \\
\hline $\begin{array}{l}\text { Ward } \\
\text { et al. }{ }^{15}\end{array}$ & $\begin{array}{l}1999-2000 \\
\text { NCDB }\end{array}$ & $\begin{array}{l}\text { All types } \\
\text { combined, } \\
\text { plus more } \\
\text { detailed } \\
\text { analyses of } \\
\text { breast and } \\
\text { colorectal } \\
\text { cancer }\end{array}$ & $\begin{array}{l}\text { Men and } \\
\text { women } \\
\text { ages 18-64 }\end{array}$ & $\begin{array}{l}\text { Private } \\
\text { insurance, } \\
\text { Medicaid } \\
\text { insurance, \& } \\
\text { uninsured }\end{array}$ & $\begin{array}{l}\text { Five-year all } \\
\text { cause survival }\end{array}$ & $\begin{array}{l}\text { Cox } \\
\text { proportional } \\
\text { hazards } \\
\text { regression } \\
\text { analysis that } \\
\text { included } \\
\text { insurance } \\
\text { status, income } \\
\text { based on zip } \\
\text { code, age, } \\
\text { race, and sex }\end{array}$ & $\begin{array}{l}\text { Privately insured patients exhibited } \\
\text { better survival than did Medicaid } \\
\text { or uninsured patients across } \\
\text { all types combined. Privately } \\
\text { insurance patients with breast or } \\
\text { colorectal cancer also had better } \\
\text { survival than did corresponding } \\
\text { uninsured Medicaid patients in } \\
\text { separate analyses by race/ethnicity } \\
\text { and stage at diagnosis. }\end{array}$ \\
\hline
\end{tabular}

$\mathrm{BCS}=$ breast-conserving surgery; $\mathrm{BMT}=$ bone marrow transplant; $\mathrm{Cl}=$ confidence interval; $\mathrm{FFS}=$ fee-for-service; $\mathrm{GLS}=$ generalized least-squares; $\mathrm{HMO}=$ health maintenance organization; $\mathrm{HR}=$ hazard ratio; $\mathrm{HRQOL}=$ health-related quality of life; $\mathrm{NCDB}=$ National Cancer Data $\mathrm{Base} ; \mathrm{NCI}=\mathrm{National}$ Cancer Institute; $\mathrm{PPO}=$ preferred provider organization; SEER = Surveillance, Epidemiology, and End Results 
Overall, these results suggest that insurance status is not a consistent predictor of cancer treatment. However, the limited number of available studies and the potentially nongeneralizable populations included in the studies (either from single institutions or single states) make drawing firm conclusions difficult. Additional research is needed to assess more thoroughly associations between insurance status and cancer treatment patterns. Studies should evaluate relationships between insurance and both guidelinebased care and new treatment modalities.

\section{Studies of Health Insurance and Cancer Outcome}

Three of the studies reviewed in the previous section $^{26,30,37}$ reported that certain groups of Medicaid patients with cancer were at greater risk of death than were non-Medicaid patients. Nine additional studies included in this report also examined associations between insurance and health outcomes among cancer patients. ${ }^{15,34,35,42-47}$ Eight of these found that uninsured or Medicaid patients had worse health outcomes than privately insured patients. ${ }^{15,35,42-47}$ Of these, three were based on data from single states. Roetzheim et al., ${ }^{35}$ using data from the 1995 Florida Cancer Registry, found that uninsured and Medicaid colorectal cancer patients had greater all-cause mortality rates compared with privately insured colorectal cancer patients. Similarly, based on data from the 1995-1998 Kentucky Cancer Registry, McDavid et al. ${ }^{42}$ found (while adjusting for age, sex, race, stage at diagnosis, treatment, and year of follow-up) that uninsured and Medicaid patients with breast or lung cancer had significantly greater all-cause mortality than did privately insured patients, while Medicaid patients with colorectal or prostate cancers also had greater mortality compared with privately insured patients.

Bradley et al. ${ }^{43}$ used Michigan Tumor Registry data linked to Medicaid enrollment files to examine survival for adults less than 65 years of age diagnosed with breast, colorectal, or lung cancer during 19961997. Medicaid patients enrolled before their cancer diagnosis were evaluated separately from patients enrolled after diagnosis. The risk of all-cause death for both groups of Medicaid patients was significantly greater than that for non-Medicaid patients, across all included type, stage, and sex strata. That is, Medicaid patients (whether enrolled before or after diagnosis) were more likely to die following a cancer diagnosis compared with non-Medicaid patients when matched by cancer type, sex, and early- versus late-stage diagnosis. However, the risk of death was not significantly different between Medicaid patients enrolled before versus after cancer diagnosis.

Five studies reported significantly worse outcomes for uninsured or Medicaid patients based on national data sources. Using hospital discharge data from the 1997-1998 National Inpatient Sample, Kelz et al. ${ }^{44}$ found that Medicaid (but not uninsured) colorectal cancer patients were at higher risk for in-hospital mortality and postoperative complications than their privately insured counterparts. Allareddy and Konety ${ }^{45}$ used the 2000-2003 Nationwide Inpatient Sample to evaluate in-hospital mortality among patients with a primary diagnosis of head and neck cancer $(\mathrm{N}=24,803)$. Patients who were self-pay/ no charge/other had $1.42(p<0.01)$ greater odds of in-hospital mortality compared with patients with private insurance. While these two studies give further insight into the problems of inadequate access to care, they lack information on disease stage at diagnosis and other patient-related factors that can substantially impact patient survival.

Kirsner et al. ${ }^{46}$ evaluated differences in survival of patients with breast cancer and colorectal cancer at diagnosis between patients with Medicare FFS and Medicare HMO coverage using the National Cancer Institute's SEER data linked with Medicare claims. Medicare HMO patients had significantly improved survival for both breast cancer $(\mathrm{HR}=0.91,95 \% \mathrm{CI}=$ 0.88-0.93) and colorectal cancer (HR $=0.94,95 \%$ CI $=0.92-0.97)$ compared with Medicare FFS patients. These results are likely due, in part, to a greater likelihood of HMO patients' using preventive services such as cancer screening. However, HMO patients also tend to be healthier than FFS patients before enrollment, which could influence these findings.

Ward et al. ${ }^{15}$ analyzed $1999-2000$ data from the NCDB to assess all-cause mortality among individuals with cancer. Survival analyses using proportional hazards regression controlled for age 
at diagnosis, race/ethnicity, sex, and zip code based household income. For all cancer types combined, patients who were uninsured and those who were Medicaid-insured at the time of diagnosis were 1.6 times more likely to die in five years compared with those with private insurance. More detailed analyses of survival following breast cancer or colorectal cancer diagnosis were also performed. For both of these cancer types, with all disease stages combined, significantly increased 5-year all-cause mortality was consistently observed among Medicaid and uninsured individuals in separate analyses of white, black, and Hispanic patients. ${ }^{15}$

Stage-specific 5-year mortality was also greater for uninsured and Medicaid patients (compared with privately insured patients) with breast or colorectal cancer in separate analyses by race and by ethnicity. Analyses of stage-specific 5-year survival for colorectal cancer patients showed that privately insured white and black patients with Stage II disease had greater 5-year survival than did uninsured or Medicaid patients with Stage I disease. Similarly, privately insured white and black colorectal cancer patients with Stage III disease had better survival than did corresponding Medicaid and uninsured patients with Stage II disease. ${ }^{15}$

Okunade et al. ${ }^{47}$ analyzed state-level data from 1990 to 1997 from a variety of sources, including the BRFSS; NCI's SEER registry; and the US Bureau of the Census. In an ecological analysis, these investigators found that breast cancer mortality was greater among women living in states with higher rates of uninsured or Medicaid populations. However, this study also reported higher breast cancer mortality rates for states with higher income or education levels. Given the ecological nature of this study (rather than patientbased analyses, as used in other studies included), it is difficult to differentiate the impact of insurance status versus breast cancer incidence (which may be greater in women with higher income/education) on breast cancer mortality.

Only one study we identified found no association between insurance coverage and survival for cancer patients. Roetzheim et al. ${ }^{34}$ analyzed data from breast cancer patients younger than 65 diagnosed in Florida and followed through 1997. Stage-adjusted survival for uninsured and Medicaid patients was not significantly different from that of privately insured patients. In this study, the authors concluded that differences in survival by insurance status reflected differences in stage at diagnosis.

Although mortality is the final outcome measure for any condition, cause-specific mortality provides a more specific measure than does all-cause mortality. However, the studies reviewed above generally included only all-cause mortality. Cause-specific mortality is more difficult to obtain, often requiring death certificates or linkage with the National Death Index, and it does have limitations regarding the listed cause or causes of death. In assessments of associations between insurance status and cancer outcomes, evaluating morbidity and related outcomes such as health-related quality of life would also be useful. Unfortunately, almost no information is available on the association between insurance status and morbidity or quality of life among cancer patients. The one study in this area that we identified 48 investigated the association of insurance coverage with quality of life among prostate cancer patients using data from the 1995-1998 CaPSURE database. CaPSURE (Cancer of the Prostate Strategic Urologic Research Endeavor) is a longitudinal observational study of prostate cancer patients nationwide, with more than 11,000 enrolled patients (http://www.capsure.net). This study found that lack of health insurance was associated with decreased quality of life, measured by both generic and diseasespecific instruments.

The majority of studies included in this section indicate an association between insurance status and outcomes, but many of them were unable to control fully for patient socioeconomic status. Socioeconomic status is strongly associated with health outcomes (both morbidity and mortality) and with insurance status. For that reason, caution must be exercised in attempting to link insurance status with long-term or final health outcomes without taking into account other relevant patient characteristics. 


\section{Discussion}

Although the literature summarized in this synthesis provides somewhat mixed evidence, the overall finding is that insurance status is significantly associated with use of cancer screening services, cancer stage at diagnosis, and survival outcomes. The relationship between insurance status and cancer treatment patterns or outcomes is less clear, but a relationship likely exists for certain types of treatment.

The studies we included have several strengths. Using data from a diverse range of sources and differing geographic regions, they generally found similar results. Several studies used data from national health care surveys or large-scale registries, and so they are generalizable to the entire US cancer population or to large subsets of this population. Many of the analyses found significant impacts of insurance status while controlling for sociodemographic factors such as race or ethnicity, income, and/or education.

Multiple limitations are associated with the studies reviewed. Many studies involved patients from a single institution or state, and they have limited generalizability on their own. Insurance status, the characteristics on which this literature synthesis focused, is based on self-report in some studies (e.g., those using data from national health care surveys) and may be subject to bias. Even in those studies with verified information on health insurance status (e.g., based on hospital billing information), there is little or no information on the duration of insurance coverage before cancer diagnosis, the type of preventive or screening services covered by the insurance, and the deductibles, co-payments, and other out-of-pocket expenses that may influence use of cancer screening, diagnostic, and treatment services. Several studies included only limited insurance status groups; for example, several studies included only Medicare patients. Even though comparisons between individuals with Medicare alone versus those with dual Medicare-Medicaid coverage are important, these results are not likely to be generalizable to younger cancer patients.

Further, the insurance status groups examined in the reviewed studies do not represent homogenous populations. Although the majority of uninsured cancer patients likely have incomes that are too low to purchase health insurance, a minority of this population (particularly younger adults) may choose not to purchase insurance despite having adequate income. ${ }^{49,50}$ The privately insured population comprises individuals with a tremendous range of plan types, each with variation in covered services, out-of-pocket expenses, lifetime expenditure limitations, and pre-approval requirements. Clearly, having private insurance does not necessarily imply that all needed cancer-related services are covered; many private insurance plans may be inadequate, and cancer patients with these plans find themselves to be underinsured.

Few studies have assessed associations between insurance status and cancer treatment patterns or outcomes. The main outcome studied with respect to insurance status is all-cause mortality, which is not likely to differentiate the impact of treatment patterns or quality of care as specifically as would cause-specific mortality. Little information is available on the relationship between insurance status and delays in care, which are likely to affect both stage at diagnosis and patient outcome. Further, studies combining patients with different cancer types and/or insurance types into a single group may miss associations of individual cancer or insurance types with treatment patterns and health outcomes. For example, studies that analyzed the association of insurance status and compliance with guideline-approved therapies among multiple types of cancer combined may not detect some effects because insurance status may affect compliance with treatment guidelines differently by type of cancer.

Multiple barriers other than insurance status also affect receipt of timely medical care. These include both patient factors (e.g., low interest in screening, lack of trust in the health care system) and healthsystem factors (e.g., availability of information in formats or languages that can be understood by patients, ease of transportation to medical care facilities). Although our literature synthesis indicates that lack of adequate insurance is an important factor regarding decreased use of cancer screening services and is probably associated with decreased medical 
care quality and outcomes, addressing lack of health insurance or inadequate insurance alone is unlikely to resolve all disparities in cancer screening and treatment.

The reviewed studies strongly indicate that insurance status is associated with screening utilization and early diagnoses, and it may be associated with treatment and its outcomes. In particular, individuals with private insurance and/or Medicare coverage are more likely to have greater utilization of cancer screening services, to be diagnosed at earlier stages, and to have better clinical outcomes than do those who are uninsured or have Medicaid coverage. More research is needed to evaluate fully the effects of type of insurance status on outcomes of screening and subsequent cancer patient care. Links between these components of care must be explored, to understand the mechanisms by which insurance status affects stage at diagnosis, treatment patterns, and outcomes. For example, do lack of insurance and other factors affecting access to care lead to delays in follow-up from abnormal screening results or scheduling of timely and high quality cancer treatment?
Finally, the research suggests that the benefits of extending appropriate insurance coverage to uninsured and underinsured individuals could be substantial. These benefits are likely to include reduced morbidity, improved quality of life, and increased survival for cancer patients as well as a positive impact on overall health care and societal costs.

\section{Conclusions}

Individuals who are uninsured or have insurance coverage through Medicaid programs are significantly less likely to receive cancer screening services and significantly more likely to present with advanced stage cancer at diagnosis. These individuals also have significantly worse survival. The available evidence (from fewer studies) also suggests that uninsured cancer patients are likely to receive less optimal treatment. Providing appropriate and adequate insurance coverage for all uninsured and underinsured individuals will likely expand cancer screening for underserved populations, increase prevention and early detection of cancer, and improve outcomes for cancer patients.

\section{References}

1. Weissman JS, Epstein AM. Falling through the safety net: insurance status and access to health care. Baltimore, MD: Johns Hopkins University Press; 1994.

2. Rowland D, Feder J, Keenan P. Uninsured in America: the causes and consequences. In: Altman S, Reinhardt U, Shields A, editors. The future US healthcare system: who will care for the poor and uninsured? Chicago: Health Administration Press; 1998. p. 25-44.

3. American College of Physicians-American Society of Internal Medicine (ACP-ASIM). No health insurance? it's enough to make you sick. Philadelphia: ACP-ASIM; 2000.

4. Hafner-Eaton C. Physician utilization disparities between the uninsured and insured. comparisons of the chronically ill, acutely ill, and well nonelderly populations. JAMA. 1993;269:787-92.
5. Thorpe KE, Howard D. Health insurance and spending among cancer patients. Health Aff (Millwood) 2003;Suppl Web Exclusives 2003:W3189-98.

6. Qureshi M, Thacker HL, Litaker DG, Kippes C. Differences in breast cancer screening rates: an issue of ethnicity or socioeconomics? J Wom Health Gend Based Med. 2000;9(9):1025-31.

7. Ayanian JZ, Weissman JS, Schneider EC, Ginsburg JA, Zaslavsky AM. Unmet health needs of uninsured adults in the United States. JAMA. 2000;284(16):2061-69.

8. Ioannou GN, Chapko MK, Dominitz JA. Predictors of colorectal cancer screening participation in the United States. Am J Gastroenterol. 2003;98(9):2082-91. 
9. Pollack LA, Blackman DK, Wilson KM, Seeff LC, Nadel MR. Colorectal cancer test use among Hispanic and non-Hispanic US populations. Prev Chronic Dis. 2006;3(2):A50.

10. Ross JS, Bradley EH, Busch SH. Use of health care services by lower-income and higher-income uninsured adults. JAMA. 2006;295(17):2027-36.

11. Coughlin SS, Uhler RJ, Bobo JK, Caplan L. Breast cancer screening practices among women in the United States, 2000. Cancer Causes Control. 2004;1592):159-70.

12. Sambamoorthi U, McAlpine DD. Racial, ethnic, socioeconomic, and access disparities in the use of preventive services among women. Prev Med. 2003;37(5):475-84.

13. Echeverria SE, Carrasquillo O. The roles of citizenship status, acculturation, and health insurance in breast and cervical cancer screening among immigrant women. Med Care. 2006;44(8):788-92.

14. Potosky AL, Breen N, Graubard BI, Parsons PE. The association between health care coverage and the use of cancer screening tests. Results from the 1992 National Health Interview Survey. Med Care. 1998;36:257-70.

15. Ward E, Halpern M, Schrag N, Cokkinides V, DeSantis C, Bandi P, et al. Association of insurance with cancer care utilization and outcomes. CA Cancer J Clin. 2008;58(1):9-31.

16. Carrasquillo O, Pati S. The role of health insurance on Pap smear and mammography utilization by immigrants living in the United States. Prev Med 2004;39(5):943-50.

17. Almeida RA, Dubay LC, Ko G. Access to care and use of health services by low-income women. Health Care Financ Rev. 2001;22(4):27-47.

18. Chen JY, Diamant A, Pourat N, Kagawa-Singer M. Racial/ethnic disparities in the use of preventive services among the elderly. Am J Prev Med. 2005;29(5):388-95.
19. Koroukian SM, Xu F, Dor A, Cooper GS. Colorectal cancer screening in the elderly population: disparities by dual MedicareMedicaid enrollment status. Health Serv Res. 2006;41(6):2136-54.

20. Parker J, Gebretsadik T, Sabogal F, Newman J, Lawson HW. Mammography screening among California Medicare beneficiaries: 1993-1994. Am J Prev Med. 1998;15(3):198-205.

21. McCoy CB, Pereyra M, Metsch LR, ColladoMesa F, Messiah SE, Sears S. A community-based breast cancer screening program for medically underserved women: its effect on disease stage at diagnosis and on hazard of death. Rev Panam Salud Publica. 2004;15(3):160-7.

22. Halpern MT, Bian J, Ward EM, Schrag NM, Chen AY. Insurance status and stage of cancer at diagnosis among women with breast cancer. Cancer. 2007;110(2):403-11.

23. Halpern MT, Ward EM, Pavluck AL, Schrag NM, Bian J, Chen AY. Association of insurance status and ethnicity with cancer stage at diagnosis for 12 cancer sites: a retrospective analysis. Lancet Oncol. 2008;9(3):222-31.

24. Chen AY, Schrag NM, Halpern MT, Ward EM. The impact of health insurance status on stage at diagnosis of oropharyngeal cancer. Cancer 2007;110:395-402.

25. Chen AY, Schrag NM, Halpern M, Stewart A, Ward EM. Health insurance and stage at diagnosis of laryngeal cancer: does insurance type predict stage at diagnosis? Arch Otolaryngol Head Neck Surg. 2007;133(8):784-90.

26. Bradley CJ, Given CW, Roberts C. Disparities in cancer diagnosis and survival. Cancer. 2001;91(1):178-88.

27. O’Malley CD, Shema SJ, Clarke LS, Clarke CA, Perkins CI. Medicaid status and stage at diagnosis of cervical cancer. Am J Public Health. 2006;96(12):2179-85. 
28. Roetzheim RG, Pal N, Tennant C, Voti L, Ayanian JZ, Schwabe A, et al. Effects of health insurance and race on early detection of cancer. J Natl Cancer Inst. 1999;91(16):1409-15.

29. Hahn KM, Bondy ML, Selvan M, Lund MJ, Liff JM, Flagg EW, et al. Factors associated with advanced disease stage at diagnosis in a population-based study of patients with newly diagnosed breast cancer. Am J Epidemiol. 2007;166(9):1035-44.

30. Bradley CJ, Given CW, Roberts C. Correlates of late stage breast cancer and death in a Medicaid-insured population. J Health Care Poor Underserved. 2003;14(4):503-15.

31. Bradley CJ, Given CW, Roberts C. Late stage cancers in a Medicaid-insured population. Med Care. 2003;41(6):722-8.

32. Bradley CJ, Given CW, Dahman B, Luo Z, Virnig BA. Diagnosis of advanced cancer among elderly Medicare and Medicaid patients. Med Care. 2007;45(5):410-9.

33. Mitchell JM, Meehan KR, Kong J, Schulman KA. Access to bone marrow transplantation for leukemia and lymphoma: the role of sociodemographic factors. J Clin Oncol. 1997;15(7): 2644-51.

34. Roetzheim RG, Gonzalez EC, Ferrante JM, Pal N, Van Durme DJ, Krischer JP. Effects of health insurance and race on breast carcinoma treatments and outcomes. Cancer. 2000;89(11):2202-13.

35. Roetzheim RG, Pal N, Gonzalez EC, Ferrante JM, Van Durme DJ, Krischer JP. Effects of health insurance and race on colorectal cancer treatments and outcomes. Am J Public Health. 2000;90(11):1746-54.

36. Voti L, Richardson LC, Reis I, Fleming LE, Mackinnon J, Coebergh JW. The effect of race/ ethnicity and insurance in the administration of standard therapy for local breast cancer in Florida. Breast Cancer Res Treat. 2006;95(1):89-95.
37. Bradley CJ, Given CW, Roberts C. Race, socioeconomic status, and breast cancer treatment and survival. J Natl Cancer Inst. 2002;94(7):490-6.

38. Parviz M, Cassel JB, Kaplan BJ, Karp SE, Neifeld JP, Penberthy LT, et al. Breast conservation therapy rates are no different in medically indigent versus insured patients with early stage breast cancer. J Surg Oncol. 2003;84(2):57-62.

39. Harlan LC, Greene AL, Clegg LX, Mooney M, Stevens JL, Brown ML. Insurance status and the use of guideline therapy in the treatment of selected cancers. J Clin Oncol. 2005;23(36):9079-88.

40. Wu X, Chen VW, Andrews PA, Chen L, Hsieh $\mathrm{M}$, Fontham ETH. Treatment patterns for stage III colon cancer and factors related to receipt of postoperative chemotherapy in Louisiana. J La State Med Soc. 2004;156(5):255-61.

41. Richardson LC, Tian L, Voti L, Hartzema AG, Reis I, Fleming LE, et al. The roles of teaching hospitals, insurance status, and race/ethnicity in receipt of adjuvant therapy for regional-stage breast cancer in Florida. Am J Public Health. 2006;96(1):160-6.

42. McDavid K, Tucker TC, Sloggett A, Coleman MP. Cancer survival in Kentucky and health insurance coverage. Arch Intern Med. 2003;163(18):2135-44.

43. Bradley CJ, Gardiner J, Given CW, Roberts C. Cancer, Medicaid enrollment, and survival disparities. Cancer. 2005;103(8):1712-8.

44. Kelz RR, Gimotty PA, Polsky D, Norman S, Fraker D, DeMichele A. Morbidity and mortality of colorectal carcinoma surgery differs by insurance status. Cancer. 2004;101(10):2187-94.

45. Allareddy V, Konety BR. Characteristics of patients and predictors of in-hospital mortality after hospitalization for head and neck cancers. Cancer. 2006;106(11):2382-8. 
46. Kirsner RS, Ma F, Fleming L, Federman DG, Trapido E, Duncan R, et al. The effect of Medicare health care delivery systems on survival for patients with breast and colorectal cancer. Cancer Epidemiol Biomarkers Prev. 2006;15(4):769-73.

47. Okunade AA, Karakus MC. Mortality from breast carcinoma among US women: the role and implications of socio-economics, heterogeneous insurance, screening mammography, and geography. Health Care Manag Sci. 2003;6(4):23748.

48. Penson DF, Stoddard ML, Pasta DJ, Lubeck DP, Flanders SC, Litwin MS. The association between socioeconomic status, health insurance coverage, and quality of life in men with prostate cancer. J Clin Epidemiol. 2001;54(4):350-8.
49. Collins SR, Schoen C, Kriss JL, Doty MM, Mahato B. Rite of passage? Why young adults become uninsured and how new policies can help. Issue Brief (Commonw Fund) 2006;20:1-14.

50. Dubay L, Holahan J, Cook A. The uninsured and the affordability of health insurance coverage. Health Aff (Millwood). 2007;26(1):w22-30. 


\section{Acknowledgments}

Portions of this work were completed when Ms. Marlow, Dr. Bian, and Dr.

Halpern were with the Department of Epidemiology and Surveillance Research, American Cancer Society, Atlanta, Georgia. 
RTI International is an independent, nonprofit research organization dedicated to improving the human condition by turning knowledge into practice. RTI offers innovative research and technical solutions to governments and businesses worldwide in the areas of health and pharmaceuticals, education and training, surveys and statistics, advanced technology, international development, economic and social policy, energy and the environment, and laboratory and chemistry services.

The RTI Press complements traditional publication outlets by providing another way for RTI researchers to disseminate the knowledge they generate. This PDF document is offered as a public service of RTI International. More information about RTI Press can be found at www.rti.org/rtipress. 